\title{
The Authors and the Rosicrucian Worldview
}

The Rosicrucian manifestos articulated that the brethren's principal aim was a reformation of religion, politics, and knowledge (scientia) or philosophy. Religiously, politically, and philosophically, they described a world that was in a dire state of decay and which they hoped to revive, restore, and renew to full splendour and glory. In the previous chapters, these ambitions were traced back to heterodox religious and philosophical sources, and were shown to be antithetical to confessional interpretations of history and to established education. But a study of these ideas in relation to the alleged authors of the manifestos has remained a desideratum. Having established the contents of the Rosicrucian manifestos and the movements, traditions, and writings their authors may have drawn upon, it is now appropriate to turn to the origins of these texts themselves.

The Rosicrucian manifestos were published in 1614, 1615, and 1616, respectively. Both the Fama and the Confessio were published anonymously by Wilhelm Wessel at the court printing press of the German Landgrave Moritz von Hesse-Kassel (1572-1632) in Kassel. The language of the first published edition of the Fama was German, and appended to it was the Answer to the Commendable Fraternity of the Theosophers of Rosencreutz by the theosopher Adam Haslmayr, which will be discussed in the next chapter. Prefixed to the Fama was a German translation of chapter 77 of the satirical work News from Parnassus (Venice, 1612) by Traiano Boccalini (1556-1613), which carried the title General and Universal Reformation of the Entire World. ${ }^{1}$ In this satirical text, wise men discuss the evils of the time and the need for a universal reformation. They proffer solutions as absurd as they are impossible, including the plan to abolish all financial trades and the suggestion that windows be placed in human hearts to allow the character of each individual to be immediately established. ${ }^{2}$ As none

1 The full title of the Fama, together with the texts by Boccalini and Haslmayr, reads: Allgemeine und General REFORMATION, der gantzen weiten Welt. Beneben der FAMA FRATERNITATIS, deß Löblichen Ordens des Rosencreutzes/ an alle Gelehrte und Häupter Europae geschrieben: auch einer kurtzen RESPONSION, von dem Herrn Haselmeyer gestellet/ welcher deßwegen von dem Jesuitern ist gefänglich eingezogen/ und auff eine Galleren geschmiedet: Itzo öffentlich in Druck verfertiget/ und allen trewen Hertzen communiciret worden. On Haslmayr, see below, section 4.1.

2 Penman, "Traiano Boccalini's Ragguagli di Parnaso," 104. About the text, see especially: Hendrix, Traiano Boccalini fra erudizione e polemica. Studi sulla fortuna di un'opera satirica 
of the solutions are practically realisable, the wise scholars instead decide to implement superficial changes only, such as determining fixed prices for fruit. ${ }^{3}$

During the following year, 1615 , the Confessio was published several times in both Latin and German. The first Latin edition was published in Kassel alongside a German edition of the Confessio and a republication of the Fama. Within a few months, a second Latin edition of the Confessio followed from the same publisher, which was prefixed by a text written by the pseudonymous Philippus a Gabella, entitled Brief Consideration of the Secret Philosophy. The latter text relies heavily on John Dee's Monas Hieroglyphica, but also resembles the Emerald Tablet attributed to Hermes Trismegistus with respect to the microcosmmacrocosm analogy and the alchemical references it included. ${ }^{4}$

Despite some similarities between these two manifestos and the texts with which they were printed, it is likely that neither the reformation plans of Boccalini's text nor the alchemical contents of the Brief Consideration had prompted the authors of the Fama and Confessio to append their writings to these works, for the simple reason that they were possibly not at all involved in the publication process and perhaps even dreaded the manifestos' publication. ${ }^{5}$ After all, the contents of the manifestos had already proven dangerous for several years, at least since Haslmayr's unfortunate fate brought him to the galleys in $1612 .{ }^{6}$ That the Fama was printed with a section from the News from Parnassus was presumably the direct result of Landgrave Moritz von Hesse's involvement in the publication process, as the Fama could probably only have been printed with the explicit permission of Moritz. ${ }^{7}$

nella coscienza politica europea, 89-92, 227-228; Penman, "Traiano Boccalini's Ragguagli di Parnaso." Besides the three Rosicrucian texts discussed here, Kienast took the Allgemeine und Generalreformation for a fourth Rosicrucian work in his Johann Valentin Andreae und die Vier echten Rosenkreutzer-Schriften, 2-3.

3 Penman, "Traiano Boccalini's Ragguagli di Parnaso."

4 Secretioris Philosophiae Consideratio brevis a Philippo a Gabella Philosophiae St. Conscripta, et nunc primum una cum Confessione Fraternitatis R.C. It is unclear by whom the pseudonym 'Philippo a Gabella' was used. Moran has argued that the author was Raphael Eglin, while Gilly suspects that the text may have been written by Johannes Rhenanus; see: Moran, "Alchemy, Prophecy and the Rosicrucians," 112; Gilly, Cimelia Rhodostaurotica, 73. For an introduction to the Consideratio Brevis, including the alchemical references and the links to the Emerald Tablet and John Dee, see: Clulee, "Astronomia Inferior," 197-234. Because of the connection with John Dee, Yates argued that the Rosicrucian movement was influenced by Dee; see:Yates, The Rosicrucian Enlightenment. This thesis has been challenged by, amongst others: Gilly, Cimelia Rhodostaurotica, 22; McIntosh, Rosicrucianism, 29; Åkerman, Rose Cross over the Baltic, 6869, 80; Clulee, "Astronomia Inferior," 225; Kahn, "The Rosicrucian Hoax in France," 236-237.

5 Gilly, Cimelia Rhodostaurotica, 70; Clulee, "Astronomia inferior," 197.

6 Cf. below, section 4.1.

7 Gilly, Cimelia Rhodostaurotica, 70; Penman, "Traiano Boccalini's Ragguagli di Parnaso." This 
The last of the Rosicrucian texts that appeared in print was the German Chemical Wedding, published in Strasbourg by Lazarus Zetzner in 1616, where the Chemical Theatre was also published. This allegorical tale was published as a separate text, was not appended to other writings, and it is the only Rosicrucian work with an avowed authorship. The German author and theologian Johann Valentin Andreae (1586-1654) confessed to having written the Chemical Wedding in his autobiography entitled Vita, a memoir written in 1642 but which remained unpublished until it appeared in a 1799 German translation. Having reluctantly acknowledged his authorship, Andreae immediately dismissed the Chemical Wedding as a "ludibrium," a mere play. ${ }^{8}$ He claimed to have written it in 1605 , when he was approximately 19 years old. But as many writings dated to that same year were actually written later, it may well be that also the Chemical Wedding was written at a later stage. ${ }^{9}$ In any event, the text had been written by 1607, because in that year Karl Widemann $\left(1555^{-1637)}\right.$, the Paracelsian physician, collector of heterodox texts, and friend of Adam Haslmayr, wrote the following about a friend and temporary co-tenant of Andreae: "M. Winter. Printer in Lauingen. He has the Alchemical Wedding $[\ldots]^{\prime 10}$ —from which remark it may be concluded that the narrative existed by that time.

The origins of the first two Rosicrucian writings are of far greater significance in the context of the topic of the general reformation, but these have proven much more difficult to determine. Written under the cover of anonymity, ever since the manifestos' publication scholars have puzzled over questions related to their origin and purpose. It has proven to be particularly difficult to pinpoint exactly when, where, and especially by whom these Rosicrucian texts were written. Answers to these questions would not only help our understanding of

is remarkable, given the fact that it was the same Moritz von Hesse-Kassel who ordered one of the first trials against the Rosicrucians; see further below, section 5.3.

Andreae, Vita, 10 (1642/1849): "Superfuerunt e contra Nuptiae Chymicae, cum monstrorum foecundo foetu, ludibrium, quod mireris a nonnullis aestimatum et subtili indagine explicatum, plane futile et quod inanitatem curiosorum prodat." Gilly commented that distancing himself from the Wedding was a tactic by Andreae to avoid criticism; see: Gilly, "Campanella and the Rosicrucians," 197. On Johann Valentin Andreae, see, for example: Kienast, Johann Valentin Andreae; Montgomery, Cross and Crucible, 2 vols. (although the latter author had a clear agenda in mind which involved distancing Andreae from the manifestos); Van Dülmen, Die Utopie einer christlichen Gesellschaft; Brecht, "Johann Valentin Andreae"; idem, Johann Valentin Andreae.

9 Andreae, Breviarium vitae, see: Brecht, "Johann Valentin Andreae," 299; Gilly, Cimelia Rhodostaurotica, 82.

10 "M. Winter. Buechdrucker in Laingen. Hat die alchimistische Hochzeit [...]," cited in: Gilly, Cimelia Rhodostaurotica, 82; Brecht, Johann Valentin Andreae, 66. Andreae lived with Winter for a year in 1607, see: Gilly, "Don Quijote und Rosenkreutz," 21. 
the origin of the manifestos themselves, but may also shed light on questions related to their authors' motives.

In the available historiography on the manifestos, much attention has been given to the question of authorship, and contextual investigations have recently provided some clues as to the origin of the manifestos themselves. ${ }^{11}$ In addition, scholars have compared the contents of the Rosicrucian manifestos with the known works of possible authors, so as to either confirm or deny their involvement. They thereby hoped to explain not only the origin of the manifestos, but also the origin and meaning of the ideas conveyed in them by tracing them back to these authors. The downside of this latter approach is that the contents of the Rosicrucian texts have not been analysed from the starting point of the manifestos themselves, but through the lens of authorship, ${ }^{12}$ a method that has also contributed to the misleading interpretation of the manifestos as Lutheran texts. ${ }^{13}$

It is not the intention here to reinterpret the contents of the manifestos in relation to their presumed authors. Having already elucidated in the previous chapters the meaning and significance of the most central theme of the manifestos - the general reformation-in this chapter we will investigate the role that this theme, in particular its apocalyptic implications as well as the reform of religion, politics, and scientia, played in their authors' other writings. To what extent were the general reformation and related themes incorporated or perhaps central to their works and worldviews? The answer to this question will provide crucial insight into the topic of the general reformation, the possible intentions the authors may have had while writing these manifestos, and it may also help to further elucidate the question of authorship.

11 See, for example: Gilly, Johann Valentin Andreae, 6o, 71-73; idem, Cimelia Rhodostaurotica, esp. 70, 77-79; idem, “Die Rosenkreuzer”; Brecht, "Johann Valentin Andreae”; idem, Johann Valentin Andreae, 65-92.

12 Peuckert, Die Rosenkreuzer, 88ff.; idem, Das Rosenkreutz, 165-173; Yates, The Rosicrucian Enlightenment, 140-155; Brecht, "Chiliasmus in Württemberg"; Wehr, "Johann Valentin Andreae," 21 ff.; Edighoffer, Les Rose-Croix, 47-58; idem, Les Rose-Croix et la crise, 24-28, 30, 51-124; Gilly, Cimelia Rhodostaurotica, 10, 12, 51-56, 75-80; idem, "Die Rosenkreuzer"; Åkerman, Rose Cross, 69-70; Dickson, The Tessera of Antilia, ch. 3; Schmidt-Biggemann, "Von Damcar nach Christianopolis"; Wels, "Die Frömmigkeit der Rosenkreuzer-Manifeste."

On the manifestos contradicting Lutheran doctrines, see Chapter 1. 
Before comparing the manifestos with the ideas of their alleged authors as they were articulated elsewhere, it is appropriate to shed some light on the question of authorship first. The author of the Chemical Wedding, Andreae, was born into a well-established family from Tübingen as the son of Johannes Andreae (1554-1601), a Lutheran theologian interested in alchemical preparations, and as the grandson of Jakob Andreae (1528-1590), a famous Lutheran theologian involved in writing the Formula of Concord. ${ }^{14}$ Tübingen, indeed, was a hotbed of orthodox Lutheranism. ${ }^{15}$ Johann Valentin Andreae could neither escape the geographically dominant religion nor the influence of his pedigree, so that he too studied to become a theologian, while also being taught in mathematical sciences by Johannes Kepler's mentor, Michael Mästlin (1550-1631).16 After his studies, Andreae became deacon in Vaihingen and pastor in Calw. From an early age, he wrote poems and comedies, which were soon followed by utopian stories. ${ }^{17}$ His religious motivations are evident from his voluminous bibliography, in which he always emphasised Christian values, the evangelical faith, and the importance of a Christian society and science.

Andreae was associated with several other Tübingen scholars, who together formed the so-called "Tübinger Kreis," the Tübingen Circle, and who have always been central to any discussion of Rosicrucian authorship. Andreae referred to this group of friends as a society, but there is little evidence that they were anything more than close and likeminded friends or that they had organised themselves in any official way. Among its members was Abraham Hölzl (dates unknown), who was a close friend of Andreae from 1608 onward, as well as Tobias Adami (1581-1643) and Wilhelm von Wense (1586-1641), who were acquainted with Campanella and who met Andreae no earlier than $1612 .{ }^{18}$ As will become clear shortly, these three men became friends with Andreae only after the composition of the manifestos. ${ }^{19}$ Central to the group, and the scholars

14 On Jakob Andreae, see for example: Kolb, Andreae and the Formula of Concord; Ehmer, Leben des Jakob Andreae:Doktor der Theologie von ihm selbst mit grosser Treue und Aufrichtigkeit beschrieben, bis auf das Jahr 1562; Ludwig, Philippismus und orthodoxes Luthertum an der Universität Wittenberg.

15 Brecht, Theologen und Theologie an der Universität Tübingen; idem, "Johann Valentin Andreae," 272; Manuel and Manuel, Utopian Thought, 289.

16 Brecht, Johann Valentin Andreae, 25-27.

17 Cf. Brecht, “'Er hat uns die Fackel übergeben ...," 29.

18 On their relation with Campanella, see above, pp. 67-68.

19 Gilly, Cimelia Rhodostaurotica, 48; idem, "Campanella and the Rosicrucians"; Böhling (ed.), Gesammelte Schriften 6. Schriften zur Christlichen Reform, 14. 
with whom Andreae is most often associated as co-authors of the manifestos, were the lawyer and Paracelsian physician Tobias Hess (1568-1614) and the lawyer Christoph Besold (1577-1638).

Hess became acquainted with Andreae before $1601 .^{20}$ Very little is known about his life and occupation, and, aside from a few letters, no works by his hand have survived. It is only from these letters and from Andreae's Vita and the Immortality of Tobias Hess (1614), the obituary Andreae wrote for him, that we learn about Hess' life and his religious, medical, and philosophical persuasions. ${ }^{21}$ Although he matriculated and graduated in law, Hess worked as a Paracelsian physician. He collaborated with Andreae's father in alchemy and cured, among others, Andreae's sister from a knee injury. In several of his writings, Andreae defended Hess against criticism that had been voiced against the latter, not least as the result of investigations into Hess' religious views and his practice as a Paracelsian physician. ${ }^{22}$ Almost twenty years his senior, Hess was revered by Andreae as a father-figure, but even more so as his teacher and friend, and as a devout Christian. ${ }^{23}$

Hess owned only a few works, most of which came after his death into the possession of Christoph Besold, a highly-educated man who owned a library containing over 4,00o writings. ${ }^{24}$ Besold was well acquainted with Andreae, but also with the theosopher Daniel Mögling, whom we will encounter in the next chapter, and with the Tübingen astronomer Johannes Kepler, whose mother was successfully defended by Besold during a witch trial. ${ }^{25}$ Besold's interests were varied, ranging from history to geography and from theology to oriental languages. He translated works by Tommaso Campanella, and published writings by the German mystic Johannes Tauler (1300-1361), the Italian Dominican friar Girolamo Savonarola (1452-1498), and the Lutheran theologian and proto-pietist Johann Arndt $\left(1555^{-1621)} \cdot{ }^{26}\right.$ Besold helped Andreae in

$20 \quad$ Gilly, Cimelia Rhodostaurotica, 48.

21 Andreae, Tobiae Hessi Immortalitas (written 1614, published 1619).

22 Cf. especially: Andreae, Tobiae Hessi Immortalitas. On investigations into Hess, see below, sections 3.2 and 3.4 .

23 Gilly, "Die Rosenkreuzer," 44.

24 The works owned by Hess include a Bible translation by Castellio, Severinus' Idea medicinae philosophicae, Lull's Ars Magna, Brocardo's interpretation of Genesis, two work by Johannes Reuchlin, and Trithemius' steganography; see: Brecht, Johann Valentin Andreae, 36. Besold's library can now be found in the Universitätsbibliothek Salzburg. The complete list of the books owned by Hess can be found in UAT, 2O/3a. Some books owned by Hess came into the possession of Christoph Schallenberg: Gilly, "Die Rosenkreuzer," 48n88.

25 Rublack, The Astronomer and the Witch, 155.

26 Gilly, Johann Valentin Andreae, 131-132; idem, Cimelia Rhodostaurotica, 65; Brecht, Johann 
his study of languages, and Andreae made avid use of his library. ${ }^{27}$ Adressing Besold, Andreae wrote: "Many people I owe very little, few a lot, you [I owe] everything." ${ }^{28}$ Besold's conversion from Lutheranism to Catholicism in 1630 , however, resulted in an ever-growing disagreement between the two scholars. ${ }^{29}$

No sooner had the manifestos appeared in print than the librarian and philologist Caspar Bucher (1554-1617) depicted Andreae as the creator of the Rosicrucian writings. Bucher's claim was made in his Antimenippus (1617), which was a direct attack on Andreae's Menippus of the same year. ${ }^{30}$ Two years later, a second scholar, Friedrich Grick, voiced his suspicions about Andreae's involvement, ${ }^{31}$ as did Melchior Breler (1589-1627), the physician to Duke August II of Brunswick-Lüneburg (1579-1666), in 1621. In his Mystery of Pseudoevangelical Evil, Breler asserted that the Fama had been written by three authors. Although he did not mention the authors' names, Breler's Mystery consisted primarily of a discussion of the Sheath of the Sword of the Spirit (Theca gladii spiritus, 1616), which was at the time attributed to Hess; of Besold's Axioms (1616), which was published with the Sheath; and of unnamed works by Andreae. ${ }^{32}$ Lastly, in 1700 the Lutheran theologian and historian Gottfried Arnold (1666-1714) concluded that Andreae was the author of the Rosicrucian manifestos. ${ }^{33}$

Despite these insinuations, several scholars in recent literature deny that Andreae had any involvement in the manifestos. On the basis of a philological comparison, especially of the Chemical Wedding with the Fama and Confessio, Richard Kienast dismissed both Andreae and Hess as possible authors of the latter two writings and concluded that the texts were written by Besold alone. ${ }^{34}$ John Warwick Montgomery, in turn, rejected the involvement of all three scholars, especially of Andreae and Besold, for reasons related to both content and

Valentin Andreae, 48, 9o. Proto-pietists are Lutherans who held pietist views before Philipp Spener (1635-1705).

27 Brecht, Johann Valentin Andreae, 46-49. Andreae described his friendship with Hess in his Vita, 47-50, 52-54, 55, 154, 207; and his friendship with Besold on pp. $20 \mathrm{ff} ., 155,178 \mathrm{ff}$., 273 .

28 "Vielen Leuten schulde ich wenig, Wenigen viel, Dir alles," cited in: Brecht, Johann Valentin Andreae, 49.

29 Brecht, Johann Valentin Andreae, 46; Salvadori, "From Spiritual Regeneration," 4-5.

30 Bucher, Antimenippus (1617).

31 On Friedrich Grick, see below, section 5.2.

32 Breler, Mysterium iniquitatis pseudo evangelicae. The text is included in Widemann's work in Augsburg and is mentioned in: Gilly, "Die Rosenkreuzer," 28-29; see also: Andreae [Hess], Theca gladii spiritus (1616); Besold, Axiomata philosophica-theologica (1616).

33 Gottfried Arnold, see: Gilly, "Die Rosenkreuzer," 29.

34 Kienast, Johann Valentin Andreae, 137, 140, 229-230. 
confession. He suggested that Andreae's religious conviction as expressed in many of his writings was at variance with the contents of the manifestos, and he repeatedly emphasised Andreae's explicit distance from the Rosicrucian story. According to Montgomery, the Paracelsian, apocalyptic, and esoteric elements of the manifestos resemble neither the Chemical Wedding nor Andreae's other writings. ${ }^{35} \mathrm{He}$ does not however provide a definite alternative to the question of authorship, but suggests that authors like Julius Sperber, Simon Studion, and Aegidius Gutman may have been involved. ${ }^{36}$ Likewise, Frances Yates does not definitively attribute the manifestos to any specific author but considers the German physician, mathematician and natural philosopher Joachim Jungius (1587-1657), a friend of Andreae who lived in the printing centre Hamburg, to be a likely candidate. ${ }^{37}$

The exclusion of Andreae as a possible author is in keeping with his own statements about the Rosicrucian story. The Second, Advisory Part of the Invitation to the Fraternity of Christ (1618) begins with a reference to the unrest caused by a certain society, that is, the Rosicrucian one. ${ }^{38}$ That fraternity, Andreae explained, was only disturbing, while "we present a more certain and more evident one."39 Published the following year (1619), his Tower of Babel, or the Chaos of Judgements about the Fraternity of the Rose Cross contained further explicit rejections of the Rosicrucian fraternity and especially of the furore that it seemed to unleash in its wake. ${ }^{40}$ Despite his apparent disdain towards it, Andreae ambiguously claimed that rather than the Rosicrucian fraternity he desired a society that "under the cross smells like roses." ${ }^{\text {I1 }}$ In this same year he

35 Montgomery, Cross and Crucible, vol. 1, 178-209. Montgomery observed a clear difference between Andreae's Lutheranism and Rosicrucianism, and he interpreted the Rosicrucian manifestos solely as outpourings of esotericism, see: ibid., 211-228.

36 Montgomery, Cross and Crucible, vol. 1, 209-210.

37 Yates, The Rosicrucian Enlightenment, 91-92. This is in the footsteps of the famous philosopher Gottfried Wilhelm Leibniz (1646-1716), who was once told that Joachim Jungius was the author of the Fama, see: Kangro, "Joachim Jungius und Gottfried Wilhelm Leibniz," 176. A more extensive overview of past positions regarding the authorship of the manifestos can be found in: Kienast, Johann Valentin Andreae, 133-137; Schick, Das ältere Rosenkreuzertum, 64n151; Peuckert, Das Rosenkreutz, 400-402; Montgomery, Cross and Crucible, 160-162; Gilly, "Die Rosenkreuzer," 35-39.

38 Andreae, Invitationis ad fraternitatem Christi pars altera paraenetica, 148 (1618).

39 Ibid., 2: "Dum animos hominum nescio quae fraternitas suspendit, nos certiorem aliquam \& evidentiorem exhibemus [...]."

40 Andreae, Turris Babel, sive judiciorum de fraternitate Rosaceae Crucis chaos (1619). Cf. Montgomery, Cross and Crucible, vol. 1, 186-187; Brecht, "Johann Valentin Andreae," 301; idem, Johann Valentin Andreae, 87.

Andreae, Turris Babel, 70: "Itaque ut fraternitatis ipsam societam quidem mitto, nunquam 
again wrote dismissively about the Rosicrucian fraternity, the manifestos, and the movement they had generated, in perhaps his most famous piece of work: the Description of the Republic of Christianopolis (1619), or Christianopolis for short. In this text, he explained that "there has been published striking evidence of a certain fraternity" which "in my opinion is a joke." ${ }^{22} \mathrm{He}$ added that "[i]t would be superfluous to say what commotion among people followed the Fama of this matter, what conflict of minds, what disturbance and gesturing of impostors and swindlers." ${ }^{43}$ Many indeed, the text continued, were deceived by the Fama. ${ }^{44}$ And in his autobiographical work, lastly, in which he had already characterised the Chemical Wedding as a "joke," Andreae stated that he had "always laughed at the Rosicrucian fable, and had chastised the little brothers for their curiosity."45 Whatever reason he may have had, Andreae denied his involvement in the production of these texts on all accounts.

There are nevertheless several reasons to question the veracity of Andreae's statements through which he intended to remove himself from the Rosicrucian story, and instead to propose that he was the author of the manifestos, perhaps in collaboration with his friend Tobias Hess. ${ }^{46}$ The fact that Besold had written in 1624 in his copy of the Fama, "autorem suspicor J.V.A.," that is, that he

tamen veram Christianam fraternitatem, quae sub Cruce Rosas olet, \& a mundi inquinamentis, confusionibus, deliriis, vanitatibusque, se quam longissime segi egat, dimisero; sed ad eam cum quovis pio, cordato, \& sagace ineundam aspiro."

42 Idem, Reipublicae Christianopolitanae descriptio (1619), 13: "Hujus rei, post illa Theologorum seria, Fraternitatis cujusdam, mea opinione ludibrium, conspicuum edidit testimonium." The subject of this sentence is missing; on its interpretation, see: Andreae, Christianopolis, ed. Thompson, 15 on3o3.

43 Andreae, Reipublicae Christianopolitanae descriptio, 14: "Hujus rei Famam quae hominum commotio secuta sit, qui ingeniorum conflictus, quae impostorum \& tenebrionum inquietudo \& gesticulatio, dicere super vacuum est."

44 Ibid., 15, see full quote below, n. 101.

45 Andreae, Vita, 183: “[...] risisse semper Rosae-Crucianam fabulam, et curiositatis fraterculos fuisse insectatum." On Andreae distancing himself from the Rosicrucian manifestos and the furore in other works, see: Montgomery, Cross and Crucible, vol. 1, 178-187; Brecht, Johann Valentin Andreae, 85-90.

46 On scholars arguing that only Andreae was involved, see: Schick, Das ältere Rosenkreuzertum, 64-96, esp. 86-87; Wehr, "J.V. Andreae," 21-22; Schmidt-Biggemann, "Von Damcar nach Christianopolis." On literature including Andreae and one or more of his friends as authors, see: Peuckert, Die Rosenkreuzer, 88-110; idem, Das Rosenkreutz, 108; Paul Arnold, Histoire des Rose-Croix, 103-112. Van Dülmen concludes that Andreae was the author of the Fama, but that the Confessio was written by others: Die Utopie, 74, 78. For scholars considering Andreae as the author, but acknowledging some influence from Hess, especially relevant are: Gilly, Cimelia Rhodostaurotica, 78; idem, "Die Rosenkreuzer," 38; Brecht, “Johann Valentin Andreae"; idem, Johann Valentin Andreae, 85-9o. 
suspected Johann Valentin Andreae to be the author of the Fama, suggests that Besold was not himself involved. ${ }^{47}$ Besold's dissociation from the manifestos leaves most prominently Hess and Andreae as possible authors.

One obvious reason for attributing authorship of the Fama and Confessio to Andreae is the fact that his family coat of arms depicts a rose and a cross, from which the name of the hero of the Fama and Confessio, "Christian Rosencreutz," seems to have been derived. ${ }^{48}$ That Rosencreutz was the protagonist also of Andreae's Chemical Wedding makes Andreae's authorship of the other two Rosicrucian texts even more plausible. There are also similarities between the Fama and Confessio and Andreae's other works. In both the Rosicrucian manifestos and in his early works such as the first and second Invitation, the Menippus, Image of a Christian Society, and the Christianopolis, Andreae described models of Christian societies, a recurring theme in his writings but apparently not a theme developed in the works of Hess or Besold. ${ }^{49}$ Descriptions in the Fama of the studies conducted in Damcar, to which Christian Rosencreutz travelled during his sojourn in the East, share further similarities with Andreae's fictive Christianopolis. ${ }^{50}$

More persuasive evidence of Andreae's involvement as an author of the Fama and Confessio is found in relation to the Sheath of the Sword of the Spirit (1616), a text that was published under Hess' name. It is now established that Andreae was the author of the Sheath, as he himself claimed authorship twenty-six years later in his Vita. ${ }^{51}$ The text of the Sheath consists of 800 aphorisms, including sentences about religious and mystical reform, and

47 Gilly, "Iter Rosicrucianum," 72; idem, Cimelia Rhodostaurotica, 62. Gilly suggests that Besold's note in his copy was possibly a tactic in order to show his lack of involvement, because Besold was about to convert to Catholicism. Besold came into the picture because he owned a manuscript copy of the Fama; see: idem, "Iter Rosicrucianum," 29.

48 The family's coat of arms was developed by Andreae's grandfather, Jakob Andreae, and Peuckert suggests, without compelling arguments, that 'Rosencreutz' was in fact a pseudonym for Jakob Andreae: Peuckert, Das Rosenkreutz, 64-65. It should be mentioned that the coats of arms of Luther and of Paracelsus also carry a rose and a cross.

49 Andreae, Invitatio fraternitatis Christi ad sacri amoris candidatos (1617); idem, Invitationis ad fraternitatem Christi pars altera paraenetica; idem, Menippus (1617); idem, Reipublicae Christianopolitanae descriptio (1619); idem, Christianae societatis imago (1620). Such similarities have been noted by, amongst others: Yates, The Rosicrucian Enlightenment, 140; Brecht, "Johann Valentin Andreae"; Gilly, Johann Valentin Andreae, 118-121; idem, Cimelia Rhodostaurotica, 75, 77; Schmidt-Biggemann, "Von Damcar nach Christianopolis." See further below, section 3.3.

$50 \quad$ Andreae, Reipublicae Christianopolitanae descriptio; see also below, section 3.3.

51 Andreae, Vita, 46: "Prodiere simul Axiomata Besoldi theologica, mihi inscripta, cum Theca gladii Spiritus, Hesso imputata, plane mea." 
was published, like the Chemical Wedding, by Zetzner in Strasbourg in 1616 . The preface suggests that the Sheath includes sentences taken from Hess' work, ${ }^{52}$ but in reality most sentences can be traced back to both published and unpublished writings by Andreae. ${ }^{53}$ Unfortunately, owing to the loss of some of his works due to multiple fires and the occasional plundering of his once extensive library, it is impossible to identify the provenance of all sentences imported into the Sheath. ${ }^{54}$ Among those that can be identified however were in fact twenty-eight sentences ${ }^{55}$ from the Confessio, which were copied almost verbatim into the Sheath (which was published the following year), which renders it even more probable that Andreae was the author of the Confessio. ${ }^{56}$ Andreae seems therefore the most likely candidate for authorship not only of the Confessio, but also, and by implication, of the closely related Fama.

Andreae's close friend and teacher Tobias Hess, the purported author of the Sheath at the time of its publication, also seems to have been involved in the composition of the manifestos. His name frequently crops up in historians' discussions regarding the origins of the Rosicrucian manuscripts. In fact, most of the copies of the Fama from before 1614 can be traced back to a copy that once belonged to Hess. ${ }^{57}$ This is confirmed in a letter by August von Anhalt, dated 21 July 1612, in which he asked Widemann to retrieve for him a copy of the Confessio from Hess, "because he [Hess] seems to have had the Fama in his

$5^{2}$ Idem, Theca gladii spiritus, 3: "Ex adversarijs Tobiae Heßij, viri pij, atque in omni litteratura, verstissimi, nunc inter sanctos agentis, hasce sententias cruimus, Candide Lector: quas (ut conijcimus) partim ex Libris manuscriptis, partim praelo vulgatis excerpsit, partim etiam ipsi suggessit piarum observatio cogitationum, quibus cum praesentem seculi nostri faciem dijudicabat, tum privatarum suarum calamitatum vincebat importunitatem." Salvadori mistakenly copies the claim that the Theca contains sentences from Hess' works: "From Spiritual Regeneration," 7n29.

53 Brecht, "Johann Valentin Andreae," 284; idem, Johann Valentin Andreae, 44.

54 Gilly, Cimelia Rhodostaurotica, 56. Edighoffer claims that the work is an anthology of five other works by Andreae; see: Edighoffer, "Rosicrucianism: from the Seventeenth to the Twentieth Century," 198. For some sentences it is actually unclear from which source they derived: Brecht, "Johann Valentin Andreae," 284; idem, Johann Valentin Andreae, 44.

55 Brecht and Gilly mistakenly mention only twenty sentences (nrs. 177-196): Brecht, "Johann Valentin Andreae," 285-286; idem, Johann Valentin Andreae, 43; Gilly, Cimelia Rhodostaurotica, 49. Gilly later claims that 27 sentences of the Theca correspond to the Confessio; see: "Die Rosenkreuzer," 51-52. Only Edighoffer and Dickson acknowledge that 28 sentences from the Confessio reappear in the Theca: Edighoffer, "Johann Valentin Andreae," 226; idem, Les Rose-Croix et société idéale, vol. 2. xv-xix; Dickson, The Tessera of Antilia, 80.

$5^{6}$ Andreae, Theca gladii spiritus, 31-35, nrs. 175-202. For these sentences, see the Appendix.

57 Gilly, "Die Rosenkreuzer," 39. 
possession. 58 And when Widemann referred to a printer in Lauingen whom he believed to own a copy of the Chemical Wedding, he added that this printer "was acquainted with Dr Hess in Tübingen."59 Hess was also familiar with the themes of the manifestos. He was interested in astrology, had studied alchemical writings, practiced Paracelsian medicine, and had made prophetic claims about a future age. ${ }^{60}$ It is therefore not surprising that, when searching for the origin of the manifestos, Andreae's and Hess' names keep reappearing, so that they remain the most likely candidates for authorship of the manifestos, and possibly co-authored the Fama and Confessio.

Not only the authors, but also the years of composition of the Rosicrucian manifestos can now be established with some confidence. 1604 is treated as an important year in the manifestos, as this is the year when Christian Rosencreutz's vault was said to have been opened and that a new celestial omen had appeared in Serpentarius, ${ }^{61}$ an event that is mentioned in the Fama. The first respondent to the Fama, Adam Haslmayr, reported in his Answer that he had read the Fama in 1610. The text must therefore have been drafted sometime between 1604 and $1610 .{ }^{62}$ It is likely that the Fama was written after 1607, because in that year, Andreae testified, he and Hess had started to work together more closely. ${ }^{63}$ The Confessio was presumably written in that same

$5^{8} \quad$ Letter by August to Widemann: "Demnach ist der grosse mangel, dass man noch zur Zeid ihre Confession nicht mag an Tan bringen, ob docht etwa, wie wol alweit beschehen sein wird, an den D[octor] van Tübingen [in marg: factum. D. Heß zue Tübingen] geschrieben hett, und vernommen, ob sich bei im zubekommen wehre, weil er [Hess] die Fama bei sich soll gehabt haben." The letter by August von Anhalt to Karl Widemann is kept in Plötzkau, 2.07.1612, Landesarchiv Oranienbaum des Landes Sachsen-Anhalt, HStA, Köthen A 17a, Nr. 100, 1-175, 120 ${ }^{\mathrm{r}}$, and cited in: Gilly, Cimelia Rhodostaurotica, 40-41; idem, "Die Rosenkreuzer," 39-40.

59 "M. Winter. Buechdrucker in Laingen. Hat die alchimistische Hochzeit. Ist mit Dr. Hess in Tübingen bekanndt gewesen," cited in: Gilly, Cimelia Rhodostaurotica, 82; Brecht, Johann Valentin Andreae, 66.

6o On Hess' views, see below. See further: Gilly, Cimelia Rhodostaurotica, 46-47; idem, "Die Rosenkreuzer," 47-50.

61 The star in the other constellation mentioned in the Confessio, in Cygnus, was already visible from 1600 onwards.

62 On several scholars with diverging and subsequently corrected datings, see: Kienast, Johann Valentin Andreae, 128, 140, 147, 15o; Peuckert, Die Rosenkreuzer, 96; idem, Das Rosenkreutz, 73-74. Van Dülmen, Die Utopie, 78.

63 Gilly, Cimelia Rhodostaurotica, 1, 48, 82; idem, "Die Rosenkreuzer," 52; Brecht, Johann Valentin Andreae, 66. Although Andreae had suggested in his Brevarium that his friendship with Hess started only in 1608, earlier, in 1607, he had proclaimed his admiration for his friend and had referred to Hess as an important physician and theologian; see: idem, Johann Valentin Andreae, 98. See also: Kahn, "The Rosicrucian Hoax," 238. 
period, between 1607 and 1610 , which is also suggested by the fact that each of the manifestos refers to the other.

The dating of these two texts is a further reason for excluding Besold as a possible author, as his friendship with Andreae became close only from 1610 onwards, that is, when the Fama was already in circulation. ${ }^{64}$ Should this dating be correct, Montgomery's suggestion that Andreae wrote the Chemical Wedding to Christianise the Rosicrucian story becomes untenable. The Wedding, after all, was written in 1607 at the latest, that is, before the Fama and the Confessio, and certainly before the manifestos' circulation, publication, and the ensuing furore. ${ }^{65}$

\subsection{Apocalyptic Expectations}

Having established with reasonable certainty Andreae's and Hess' close involvement in the production of the Rosicrucian manifestos, it is appropriate to study their other texts and ideas specifically from the perspective of the Rosicrucian general reformation. ${ }^{66}$ When it comes to the Rosicrucians' apocalyptic expectations, the chronology of epochal events, and the interpretation of

64 Brecht, "Johann Valentin Andreae," 289; idem, Johann Valentin Andreae, 46.

65 Montgomery, Cross and Crucible, vol. 1, 228. Montgomery argues that the Fama was written before the Chemical Wedding, at the end of the sixteenth century, for which reason he further excluded Andreae's involvement. Montgomery's suggestion of such an early date is based on two insufficient arguments: 1) A diary entry by Martin Crucius asserts that already in 1597 Hess and Simon Studion shared political expectations concerning the year 1604, which year, as we have seen, plays an important role in the Fama. From this it supposedly follows that ideas from the Fama date back to 1597, when Andreae was merely 11 years old. But obviously, the fact that Hess and Studion communicated about political topics at the end of the sixteenth century does not itself imply in which year the Fama was drafted; 2) The author of the Echo, which Montgomery believes was Julius Sperber, wrote in 1615 that secret ideas conveyed in the Fama were known 19 years before their publication, that is, in 1595. Montgomery suggests that this would mean that the Fama itself was known by that time: Montgomery, Cross and Crucible, vol. 1, 209-210. But the claim that ideas conveyed in the Fama were known to others is itself also conveyed in the Fama, 100-101. Sperber seems to allude to the expression of ideas similar to those expressed in the manifestos in the years before their publication; see: Sperber, Echo, front page: "Exemplarischer Beweis, Das nicht allein dasjenige was jetzt in der Fama unnd Confesion [sic] der Fraternitet R.c. ausgebotten, müglich und war sey, Sondern schon für neunzehen und mehr Jahren solche Magnalia Dei, etzlichen Gottesfürchtigen Leuten, mitgetheilet gewesen, und von ihren privatschrifften depraediciret worden."

66 As for Andreae, we will restrict ourselves to his early period until 1620, and to the writings in which he sought to depict a society. 
history, we should first analyse the views of Hess. Although none of his books have survived, we do have access to a few letters in which he explained his ideas as well as to investigations into his religious persuasions, which at times consist of little more than hardly legible scribbles by his interrogators. ${ }^{67}$ Of interest is, for example, that Hess argued that there had followed a period of 120 years of repentance after what he called the beginning of the evangelical truth. ${ }^{68}$ This 120-year period of repentance had earlier been announced by the Italian Bible interpreter Jacopo Brocardo (ca. 1518-1594?), whose commentary on Genesis was in the possession of Hess and, later, of Besold. ${ }^{69}$ For Hess, the beginning of this period of repentance coincided with the birth of Luther in $1483 / 4$. The period would end 120 years later, in $1603 / 4{ }^{70} \mathrm{It}$ is particularly striking that Hess' periodisation would later return in the Rosicrucian manifestos. In the Fama, Christian Rosencreutz is said to have died in 1484, which coincided with Luther's birth. After Rosencreutz's death, his place of burial would remain hidden for 120 years, namely until 1604 when his vault was to be revealed and simulteneously a door for Europe would be opened. ${ }^{71}$ The year that according to Hess signified the end of repentance, here foreshadows momentous changes.

In keeping with the manifestos, Hess explained that a future earthly time of peace will follow this period of 120 years. His chiliastic tendencies are recognised in Andreae's Immortality of Tobias Hess, which openly refers to Hess' belief in a future Golden Age. ${ }^{72}$ Hess seems to associate himself with the Joachimite tradition, according to which history could be divided into three statuses or ages, the last of these being a beatific period that was yet to come. ${ }^{73}$ Inspired by the Joachimite interpretation of history, Hess described the future golden period as the third age of the world. Because of his views, for which he had already become notorious, Hess was investigated by the Lutheran University of Tübingen. In a letter dated 7 June 1605, Duke Friedrich I of Württemberg (1557-1608) informed the theological faculty that "it has credibly come to our attention, that in Tübingen a new opinion of a third age is awakened and spreads, especially strongly defended by Dr Tobias Hess, who is related to that

\footnotetext{
67 These texts and reports of the investigations are kept in Tübingen. For an analysis, see also: Brecht, "Chiliasmus in Württemberg," 25-31.

68 UAT, 12/17, nr. 39, question viI: "[...] also auch vor dem Jüngsten Tag, post revelatam Veritatem Evangeliam 120 Jahr Büß gepradiget worden."

69 Brecht, "Chiliasmus in Württemberg," 31; Gilly, "Iter Rosicrucianum," 70.

70 Brecht, "Chiliasmus in Württemberg," 27; Gilly, "Iter Rosicrucianum," 70.

71 Fama, 113-114.

72 Andreae, Tobiae Hessi Immortalitas, 63.

73 On the Joachimite view of the periodisation of history, see above, section 1.2.
} 
university, and that besides that all sorts of blasphemies are uttered." ${ }^{74}$ Duke Friedrich was worried that Hess' views did not agree with Lutheran doctrines as formulated in the Formula of Concord, and he ordered the university to interrogate him..$^{75}$

Two weeks later, on 21 June 1605, members of the theological faculty questioned Hess about his confessional beliefs. ${ }^{76}$ With reference to biblical passages, Hess confirmed that he believed in a third age, which he called in Joachimite fashion "the age of the Holy Spirit." He believed that the preservation of Israel was to be fulfilled in that time. ${ }^{77}$ The upcoming new age provided a historical platform for worldly change.

In parallel with the manifestos, Hess argued that this age had already been announced by the stars. In response to the investigation, he wrote a letter to Duke Friedrich, dated 30 June 1605, in which he informed his Lord about this third age while referring to the new cycle of conjunctions of Saturn and Jupiter in the Fiery Trigon - the constellation that was later mentioned in the Fama as signalling imminent changes. ${ }^{78}$ The new cycle of conjunctions in the Fiery Trigon had begun in 1583 , with the most recent conjunction between Saturn and Jupiter taking place in December 1603, one and one half years before Hess' investigation. With such recent omens, the new period Hess announced was nigh, and must have been identical to the one he and Andreae not much later described in the first manifesto.

Hess explained to the Duke that the "great meaningful signs" close to the Fiery Trigon, possibly the stars in Serpentarius and Cygnus, signalled the imminent judgement over and destruction of the pope. The pope had "falsely pretended to be the head of all Churches," which suggests that Hess identified the pope with the Antichrist, who was to be attacked by Christ. ${ }^{79}$ When asked about this by his interrogators in Tübingen, he associated the beginning of the

74 UAT 12/17, nr. 37, letter from Duke Friedrich: "Uns langet glaublich an, das czue Tübingen ein Newe Opinion von einem tertio seculo erweckhet und spargieret, Sonderlich aber von D. Johann [in margin, corrected to 'Tobia'] Heßen, Universitet Verwandten allda starrch defendiert, und darneben allerley blasphemiae mitt ußgestoßen werden wöllen."

75 Ibid., nr. 37 .

76 Ibid., nr. 38 .

77 Ibid., nr. 38, question I: "spiritus sancti seculum"; Brecht, "Chiliasmus in Württemberg," 26.

78 UAT, $12 / 17$, nr. 40.

79 Ibid., nr. 40, letter by Hess to Duke Friedrich: "weil die Zeit nah sein muß und [so] heuffig Wunder und groß bedeuttliche Zeichen eins über ander neben dem trigono igneo gesehen und gehöret worden, welche in die Schrifft gefürt, nichts anders anbringen und vorkünden, denn daß Christus nummehr die, so sich an seiner statt gesetzt und fälschlich für das Haupt aller Kirchen außgeben, dieselben plagen, dringen und hindern [...] wölle," cited in: Gilly, Cimelia Rhodostaurotica, 43-44. 
new period with the destruction of the papal "Antichrist," which association would later recur in the manifestos. ${ }^{80} \mathrm{He}$ calculated that the future judgement of the pope would take place in 1620, after which time Christ would reign over the people in the coming third age and before the Last Judgement. ${ }^{81}$ In the third age of the Holy Spirit, "the pope will no longer be the head of the Church, but he will be decommissioned." ${ }^{22}$ Since Hess calculated that the Lamb, Christ, will triumph over Rome in 1620, this year marked the beginning of the new reformation-a prediction that was particularly close to the prophecies contained in the manifestos. ${ }^{83}$

The Rosicrucian lion, too, found its origin in Hess' expectations. Hess referred to this figure in another letter submitted to Duke Friedrich and kept in Tübingen, in which he explained that the figure of the lion had appeared to him in a vision he had as a young boy. The lion had ordered him to write down what he saw and heard. ${ }^{84}$ Years later, he described this singular event in his letter to the Duke:

And he [the lion] explained the reason of his arrival with the most horrible roaring: he had come for his people, who had for day and night and up to the mature [present] age of Christ stood guard, diligently, to fight and to punish sins through his judgement. ${ }^{85}$

8 o UAT, $12 / 17$, nr. 38, questions I and II, where Hess identifies the pope with the Antichrist.

81 Ibid., nr. 38: "Der Bapst müeß hernider, Christus müeß das Haupt werden." Cf. also ibid., question IX; UAT, 12/17, nr. 39, question III; Brecht, "Chiliasmus in Württemberg," 28; Gilly, Cimelia Rhodostaurotica, 43-44.

82 UAT, 12/17, nr. 38, question IX: “[...] wenn der Papst nicht mehr Caput Ecclesiae sondern außgemustert sein wird." See also: UAT, 12/17, nr. 38, question VIII about the third age of the Holy Spirit.

83 Ibid., nr. 38. A similar suggestion was made in Hess' copy of Castellio's Bible translation, in the margins of Apocalypse 17:12-16; see: Castellio, Biblia sacria (Salzburg copy owned by Hess and Besold), 397-398. Cf. also: Gilly, Cimelia Rhodostaurotica, 10.

84 UAT, 12/17, nr. 42: "Proprius vero multo Leo a tergo iubatus me pressit, ut omnino scriberem, calamum porrexit, ursit, nec remisit. Apparuit is mihi annis aliquoties iuvenilibus magna undiquaque cinctus caterva clare acclamantium palmasque gestantium [...]." Brecht missed the reference to the lion which appeared as the astrological sign for 'Leo'; Gilly refers to nr. 48 but the document has been changed to nr. 42: Brecht, "Chiliasmus in Württemberg," 29n12; Gilly, "Die Rosenkreuzer," 48n89. For the vision, see also: Gilly, "Die Rosenkreuzer," 48-49.

85 UAT, 12/17, nr. 42: “[...] et rugitu perquam horrendo (Jer. 25. Amos. 1.3. Joel. 3) adventus sui rationem exponebat, se pro populo suo, cuius in mensuram usque aetatis plene adultae Christi (Epsi. 4) per diem et noctem integram excubias sedulo egisset (Isa 21) modo pugnatum adventasse (Isa 34, Zeph 7) peccata iudicio vindicatum (Mich. 5, Nah. 3, Apoc. 10.18)." 
According to Hess, the present period will be ended with the lion's judgement over sin, which was identical to Christ's judgement over the papacy described earlier.

While the lion was speaking - so Hess informed the Duke-the ground began to shake and fire and stormwinds poured out of his mouth, and "even the eagle, who through time had overcome so many difficulties, gradually [becoming] featherless and mutilated, was removed without much ado from his triple throne." ${ }^{86}$ Hess must have been inspired by 2 Esdras, the pseudepigraphic apocryphal text to which he referred in his letter and in which a lion is described as defeating an eagle. ${ }^{87}$ For Hess, the eagle was to be identified with Papal Rome, which he named the "Babylonian Whore," again associating the pope with the Antichrist. ${ }^{88}$ Thus the lion was to come at the end of the second age to fight for the Christian people against the papal eagle.

The similarities with the Rosicrucian expectation of a lion are evident: According to both the manifestos and the folios documenting Hess' interrogation, a roaring lion defeats the papal enemy after a period of 120 years, at the dawn of a new age announced by the stars, with the eagle identified as Rome and the rule of its feathers destined to be annulled. ${ }^{89}$

In the Fama, the lion was a ruler who came to enact both political and spiritual change. It seems that Hess had only spiritual change in mind brought about by a spiritual ruler. In Hess' view, the lion was to pass judgement over the sinners and to become the people's leader in replacement of the papacy, and he referred to the "spiritual arrival of Christ at the time of the ruling papacy. ${ }^{\prime 0}$ This suggests an emphasis on spiritual change by Christ as ruler. ${ }^{91}$ Unlike the manifestos, Hess identified the lion with Christ, because both were to arrive as judges upon the arrival of the third age. A few lines above the explanation of his vision of the lion, he referred to the lion of Revelation 5 who opened the seventh seal, which is commonly interpreted to refer to Christ as the Lion of Judah..$^{92}$ This specific biblical context and the associated

86 Ibid., nr. 42: "Aquilam quoque tot temporum difficultates eluctatam [...] paulatim implumem et mutilam nullo negotio e triplici solio deturbabat."

$87 \quad$ On 2 Esdras, the fight between the eagle and the lion, see above, section 1.1.

88 UAT, $12 / 17$, nr. 38 ; UAT, $12 / 17$, nr. 42 . Cf. Revelation 17:9.

89 See above, section 1.1.

$90 \quad$ UAT, $12 / 17$, nr. 39, question X: "[...] per Christi spiritualem adventum tempore regnantis papatus [...]."

91 Cf. Gilly, "Die Rosenkreuzer," 49-50.

92 UAT, $12 / 17$, nr. 42. Revelation 5:4-5: "And I wept much, because no man was found worthy to open and to read the book, neither to look thereon. And one of the elders saith unto me, Weep not: behold, the Lion of the tribe of Judah, the Root of David, hath prevailed 
emphasis on spiritual change seems to be missing in the manifestos. Despite these variances in the details, Hess' overall prophetic and apocalyptic expectations were left intact. It is therefore likely that several ingredients of the manifestos-including their millenarian imagery, the place of the Antichrist within history, the lion, the eagle, and the omens in the sky-originated with Hess.

Many of these specific ingredients are not easily traced back to Andreae, although he, too, shared with all Protestants the identification of the Antichrist with the pope. ${ }^{93}$ According to Andreae, the pope had "weighed down the Church of Christ with abominable burdens." ${ }^{\prime 4}$ The Antichrist presented himself as the "earthly deity," who filled the earth with the factions of his many orders-no doubt a reference to the monastic orders. ${ }^{95}$ When the Church became increasingly powerful and wealthy, as Andreae explained elsewhere, it lost Christ possibly because the Antichrist had taken over. ${ }^{96}$

Additionally, Andreae may once have had chiliastic tendencies. In his Immortality of Tobias Hess, he explained that he once believed in a coming Golden Age, although a few lines later he makes it clear that he has distanced himself from this conception. ${ }^{97}$ In his second Invitation, he suggested that the period of eternal peace was still far away, even though much anticipated. ${ }^{98}$ And in the

to open the book, and to loose the seven seals thereof." The lion was the lamb with seven horns and seven eyes, commonly understood to be Christ.

93 At times, Andreae's definition of the Antichrist is merely a generic label applicable to everything that is opposed to Christ, see: Brecht, Johann Valentin Andreae, 114.

94 Andreae, Reipublicae Christianopolitanae descriptio, 6: "Specimen hujus evidentissimum Antichristus praebuit, qui cum nefandis oneribus Ecclesiam Christi deprimeret."

95 Idem, Christianae societatis imago, $\mathrm{A}^{\mathrm{v}}-\mathrm{A}_{3} \mathrm{r}$ : "Sed etiam antichristus ut omnino illi inviso suo Christo illuderet, variorum ordinum factionibus, Orbem replevit, non tam ut securitatem suis, voluptatemque procuraret quam ut ipse rerum omnium Primus motor, omes [sic] terrarum orbiculos suo arbitrio rotaret, orbemque his machinis undique dispersis, ad nutum moveret, atque ita Terrenam divinitatem usurparet." There are two A3 folios; this one would usually be correctly designated A2.

96 Idem, Invitatio fraternitatis Christi, 21: "Nec parvifaciendum Ecclesiam postquam ditata \& opulenta facta est, a Christo suo descivisse."

97 Idem, Tobiae Hessi Immortalitas, 63-64: "At hic calumnia tripudiare, hic jactare se illa \& quae in Chymico nequicquam dentes impresserat, nunc Naometram, nunc Chiliasten, nunc Somniatorem deprehendisse, ovans. Mirum est, quam per sordida ora candidissimum virum macularit, \& ut vulgus nuspiam, nisi mendaciis liberalius est, ita quosdam non adeo iniquos sed minus innocentis famae curiosos occupavit, me etiam, quod doleo, facile induxit, ut paradoxicum Hessi ingenium \& nescio quod aureum confictum seculum, quam judicij curiosam computationem crederemus. Qua in re quam in Hessum fuerimus injurii, quam qui in sanctissima exercitia inquireremus nimium illoti, Ego paulo post non absque rubore agnovi, \& nonnullis, qui minus calumniarum sunt tenaces, idem persuasi."

98 Idem, Invitationis ad fraternitatem Christi pars altera paraenetica, 6-7: "[...] ut quod 
Sheath he imported sentences from the Confessio that suggest a new period on earth. The first such sentence reads: "While the world is tottering and almost at the end of a period and rushes to its beginnings, God returns the order of nature $[\ldots]^{n 9}$ - which indicates that this notion of another age was not far from his own expectations. In his Christian Citizen (1619), finally, he discussed the millenarian worldview at length and argued that it could not so easily be rejected as many had done; it was not contrary to Christian faith and was therefore not to be condemned. What was to be ridiculed, by contrast, was the specific vision of a new Golden Age, but millenarianism was only dangerous when voiced by Anabaptists from Münster whose ideal was, he contended, the work of Satan. ${ }^{100}$ Andreae did therefore not reject a chiliastic conception of history, and perhaps once endorsed such a conception himself, albeit not explicitly. Nevertheless, the millenarian imagery seems to have originated with Hess, to whom its key ingredients can be traced.

\subsection{New Societies and Attempts at Reform}

The idea of a Rosicrucian organisation as a society, in turn, presumably originated with Andreae. Andreae seems always to have had the establishment of a society in mind. Despite the fact that he routinely dismissed the Rosicrucian

neutiquam tam absurdum vobis ac inexspectatumm accidere potuit, quin non Christi vestri \& aeternae quietis arcem velut e longinquo appropinquantem prospexeritis."

99 Idem, Theca gladii spiritus, 31, nr. 175: "Iehova mundo labascente, \& propemodum periodo absoluta, ad principium properante; naturae ordinem invertit." Cf. Confessio, 43: "Jehova est, qui mundo labascente, et propemodum periodo absoluta, ad principium properante Naturae ordinem invertit."

100 Andreae, Civis Christianus (1619), 141-143: "Multos bonos, jam ab aliquos seculis, haec opinio exercuit, fore ut ante Mundi finem, Christus regnum aliquod Christianum sibi ex optimis colligat, \& impietati terrenae imperet, fueruntque aliqui eo progressi, ut annos futuri hujus summi imperij annunciarent. Magna utique hujus negotii lubricitas est, quae etiam haud paucis illusit: tamen si qua sub Dei metu conjectura fiat, non plane ea contemnenda est. Praeviderunt sane sub Ecclesiae onere multi Deo dilecti liberationis felicitatem, \& infamis tyrannidis excussionem, quod plerisque tum ridiculum imo \& impium visum est. Qui tales ridere solent, ajunt aureum seculum expectare, ubi omnia sint ex voto futura. Et certe quid possit, aut velit Satan, Monasterij in Westphalia impudenter ostendit. Christianus quae non capit, non temere abijcit, si nihil contra rem Christianam moveant. Multas imagines revelationis Johanni factae nemo nobis hucusque dextere explicavit, \& rebus nostris adaptavit, quas tamen multum etiam num portendere, credibile est []. Interim Christus senescentis Mundi caligines, calamitatem, gelu [sic], terroresque, ac judicii sui in opinatum interventum praedixit, quae cum illa ultima felicitate parum convenire videntur." 
one, he explicitly invoked that fraternity as a fertile source of inspiration. In his introduction to the utopian description of Christianopolis, he questioned the existence of the Rosicrucian fraternity, but took from the Fama the ideal to form a community in imitation of the alleged Rosicrucian brotherhood. $\mathrm{He}$ explained that his close friend, the nobleman Wilhelm von Wense, had proposed, while referring to the Rosicrucian fraternity, that "if these things seem to be good, why do we not try something [similar], and not wait for them [the Rosicrucians]?"101

In other texts, too, he depicted societies that were unaffected by religious, societal, and academic malfeasance. As for religious reform, these depictions reveal that Andreae was particularly influenced by the Lutheran theologian and proto-pietist Johann Arndt (1555-1621). ${ }^{102}$ Arndt worked as a pastor in Braunschweig and Eisleben, but aimed to reform his confession under the influence of medieval German mystics such as Johannes Tauler and Thomas à Kempis (1380-1471), as well as Paracelsus. Andreae regularly praised Arndt as a reformer of Christianity who encouraged his readers to live a life of piety. ${ }^{103}$ Exemplary for Arndt's views are his famous Four Books on True Christianity, in which he admonished his readers to have faith in Christ, to follow His example, and to live in Christ. ${ }^{104}$ To be a Christian meant to live like one and this was a practical, not a theoretical endeavour. ${ }^{105}$

This is why Andreae dedicated his utopian Christianopolis to Arndt, whom he wished to "esteem as a father in Christ."106 As the city's name indicates, the community described in Christianopolis was Christian in character, and

101 Idem, Reipublicae Christianopolitanae descriptio, 15: "Soleo autem laudare Viri pietate, moribus \& ingenio nobilissimi judicium, qui cum suspensos videret, ac ut plurimum elusos ab illa Fama animos: 'quin nos, si bona haec videntur, tentamus aliquid, non expectamus illos?'” Von Wense had visited Campanella in 1614, and further suggested that Andreae should establish a "city of the sun" in imitation of Campanella's utopian story with the same title: Dickson, The Tessera of Antilia, $38 \mathrm{n} 60$.

102 On Arndt, see for example the articles included in: Gilly, "Johann Arndt und die 'dritte Reformation'"; Schneider, Der fremde Arndt. On the influence of Arndt on Andreae, see for example: Van Dülmen, Die Utopie.

103 Van Dülmen, Die Utopie, 115; Gilly, "Hermes or Luther"; Brecht, Johann Valentin Andreae, 121.

104 Arndt, Vier Bücher (1664), 2v: "[...] daß wir nicht allein an Christum glauben/ sondern auch in Christo leben sollen/ und Christus in uns/ wie die wahre Busse auß dem innersten Grund deß Herzens gehen müsse/ wie Herz/ Sinn und Mühe müsse geändert werden/ daß wir Christo und seinem H. Evangelio gleichformig werden/ wie wir durchs Wort Gottes müssen täglich erneuert werden zu neuen Creaturen."

105 Ibid., $2^{\mathrm{v}}$.

106 Andreae, Reipublicae Christianopolitanae descriptio, 3-4: "Vir reverende, et dignissime Dn. Joannes Arndti, etc. Pater in Christo colende." 
the studies practiced by its inhabitants served first and foremost the purpose of a Christian life, which meant that they lived in the type of union with Christ that Arndt had advocated. ${ }^{107}$ In his first Invitation, Andreae expressed his hope for the realisation of a community of goods in which all inhabitants were Christ's brothers, friends, and imitators. ${ }^{108}$ And in the second Invitation, he provided 24 rules of piety according to which true Christians should behave. They should for example rule over themselves, aspire to heavenly things, abandon the concern for themselves but care for their neighbours, live in simplicity, and contribute to the common good. ${ }^{109}$ Andreae explained that the reward for present conduct was not on earth but in heaven, and that one should live for the sake of the eternal life. ${ }^{110}$ His pietist inclinations are even more evident from the following quote taken from the first Invitation:

But do you not see, o brethren, that it is in our hands, that forthwith we are not taken by the admiration of superfluous things like the rest of the insane populace, and become experienced in the bitterness of the world's greatest luxuries, but let us free ourselves from many troubles, and continue on the least crooked and rough, but most straight and level path to our true rest and the end of all imperfections. Surely the safest and happiest means towards this is to establish a fraternity of Christ. ${ }^{111}$

The life of piety was not defined as a solitary pursuit but was best lived in a society. In his Image, Andreae specified about its society that "its path intends and considers nothing other than what Christ has previously already invoked, the apostles have insisted upon, the Church has propagated, and what all

107 Ibid., $15^{-17 .}$

108 Andreae, Invitatio fraternitatis Christi, $5^{-7}$. The ideal of a community of goods is also described in his Reipublicae Christianopolitanae descriptio; and in his Christiani amoris dextera porrecta, included in: Andreae, Gesammelte Schriften, vol. 6, 254-275.

109 Andreae, Invitationis ad fraternitatem Christi pars altera paraenetica. Cf. also: Andreae, Christiani amoris dextera porrecta, included in: Andreae, Gesammelte Schriften, vol. 6, 256262.

110 Andreae, Invitationis ad fraternitatem Christi pars altera paraenetica, 10-11, 31-32.

111 Idem, Invitatio fraternitatis Christi, 74-75: "Videtisne autem, o Fratres, in nostra manu esse, ut quamprimum non cum reliqua insana multitudine ineptarum rerum admiratione capimur, \& summarum etiam Mundi delitiarum amaritudines experti sumus, liberemus nos plurimis molestiis, \& via minime flexuosa ac salebrosa, sed rectissima planissimaque ad veram nostram requiem, \& imperfectionum omnium Finem pergimus. Cujus sane tutissimum atque felicissimum est medium Fraternitatem Christi intromittere." 
Christians should do."112 In keeping with Arndt's pietism, Andreae frequently described the need to move away from the world, removing its "shackles," and enjoying a Christian peace of mind. ${ }^{113} \mathrm{~A}$ society was a means particularly suitable to enact such religious and societal changes.

Like Arndt, Andreae was not a conservative Lutheran academic involved in quaestiones, but a Lutheran interested in reforming his confession according to his pietist inclinations. In his Four Books, Arndt contradicted orthodox Lutheranism, drew on heterodox sources such as Tauler, and lamented the practice of orthodox theologians at universities. ${ }^{114}$ Because of its heterodox nature, this work was censured in Marburg and was criticised by orthodox theologians belonging to the religious establishment, especially after it was linked to ideas held by the Lutheran theosopher Valentin Weigel (1533-1588). ${ }^{115}$ This was also the reason that Arndt, who had died in 1621, became the subject of a dispute in 1622 in Tübingen, Wittenberg, and Gdańsk. In response to this conflict, Andreae defended Arndt in his Theophilus of the same year. Like Arndt, he lamented academic malpractices, ridiculed the theological studies at universities, and particularly complained about established Lutheran theologians who preached their interpretations of confessional dogmas but failed to practice their faith in daily life. ${ }^{116}$ As the Theophilus was a clear response to the Arndt episode, problematised the practice of established theologians, and proposed a reform of religion, the printing of this text was prohibited in Württemberg. ${ }^{117}$

Andreae saw the establishment of a society as the right means to carry out further changes, including the reform of politics and knowledge. In 1620, one year after the publication of Christianopolis, he developed a further plan for a society. In a letter sent to Duke August II of Brunswick-Lüneburg (1579-1666) over twenty years later, dated 27 June 1642 , he related how in 1620 he had had plans to found a Christian society, the "Societas Christiana." He informed the

112 Idem, Christianae societatis imago, A3": "[...] cum nihil aliud [via] velit, exigatque quam quod Christus jam dudum inclamavit, Apostoli urserunt, Ecclesia propagat, Christiani omnes debent: scilicet Deo cultum Naturae modestiam, Humanitati eruditionem, non tam verbis, quam ipso opere servemus."

113 Ibid., A3": "[...] boni, et Coeli avidi, dum terrarum vinculis sunt impediti, semet mutua charitate et commoditatum, ornamentorumque hujus vitae communicatione solarentur, Mundi imposturas et insidias communi consilio evitarent, Ingenii humani nobilitatem rerum ab orbe nato cognitarum peritia condecorarent, denique aurea Christi pace tranquilitateque perfruerentur."

114 Gilly, "Johann Arndt," 68-69.

115 Ibid., 68-69. On Weigel, see further below, Chapters 4 and 5 .

116 Brecht, “'Er hat uns die Fackel übergeben ...," 40-43; idem, Johann Valentin Andreae, 173178.

117 Brecht, “'Er hat uns die Fackel übergeben ...,” 28, 41. 
Duke that at that time he had already wanted him to become the society's leader, because every other political ruler seemed unfit for the job. ${ }^{118}$ This is an interesting fact, because Andreae and August II, who only became Duke in 1635 , seem to have engaged in epistolary contact only from 1630 onwards, which was resumed after an interval of a decade again in 1640, but they never met. ${ }^{119}$ In a letter to August II from 1 June 1642, however, Andreae intimated that he had brought his plans for a society to the attention of August II as early as $1617,{ }^{120}$ putting his hope for change in this future political ruler. The two men do share some biographical similarities: August and Andreae had both studied in Tübingen, although not at the same time; they shared an admiration for Arndt; it is likely that they came into contact through Andreae's friend Wilhelm von Wense; and the physician to August II, Melchior Breler, had discussed the manifestos and their authorship in his Mystery in 1621, while also referring to texts by Andreae. ${ }^{121}$ It may well be that with August II we find the origin of the Rosicrucian lion figured not as Christ but as a spiritual leader and a political ruler.

In his letter, Andreae listed the intended membership of the "Societas Christiana." Besides several established Lutherans, famous and innovative early modern figures were included, indicative of an interest in the reform of knowledge and academia. Among the members was Johann Arndt, but also included were Daniel Sennert (1572-1637), Wilhelm von Wense, Tobias Adami, Matthias Bernegger (1582-1640), Christoph Besold, Tobias Hess, Wilhelm Schickard (1592-1635), and Wilhelm Bidembach von Treuenfels (ca. 1588-1655). ${ }^{122}$ The objective of the fraternity remained unknown, but the list of prospective members may give some indication of its academic and scientific character. Sennert was a professor of medicine and natural philosophy at Wittenberg who adopted alchemically prepared cures, embraced atomistic views, and used

118 Andreae, letter to Duke August, 27 June 1642, in Gesammelte Schriften, vol. 6, 343: "Hujus iam tum Tu unicus princeps et caput animo nostro destinabaris, cujus se pararium esse posse Wensius crediderat, cum nemo alius in Orbe Germaniae occurreret, cui haec rei Christianae, et literariae provincia, certius et maiore dignitate committi videretur." Numerous letters between Andreae and others are listed in: Salvadori, Inventar des Briefwechsels von Johann Valentin Andreae (1586-1654).

119 On the relationship between Andreae and Duke August II, see: Brecht, J.V. Andreae und Herzog August, esp. 74-77. This work sheds further light on Andreae's pious inclinations and his attempt to reform the Lutheran confession by reforming the people: Andreae advocated a reformation of morality. It should be noted, however, that Brecht seems to advocate a particularly Lutheran reading of Andreae and, in his Johann Valentin Andreae, 77-79, even of the manifestos.

120 Brecht, J.V. Andreae und Herzog August, 74n2.

121 Ibid., 27, 61, 74-76.

122 For the full list of members, see: Gilly, Johann Valentin Andreae, 121. 
experimental methods to test his theories. ${ }^{123}$ Bernegger worked as an astronomer and translated classical and Italian writings, among which a text by Galileo Galilei. ${ }^{124}$ The Tübingen astronomer Schickard had developed a primitive calculating device as early as 1621, several decades before Gottfried Wilhelm Leibniz created his mechanical calculator. ${ }^{125}$ Schickard was also acquainted with a Rosicrucian enthusiast from the same town, Daniel Mögling, as well as with Johannes Kepler. ${ }^{126}$

Bidembach was Hess' companion who had translated Boccalini's General Reformation, to which the Fama was appended. ${ }^{127}$ Adami belonged to the Tübingen group of friends, as did Besold and Hess. Von Wense, finally, was a close friend of Andreae. In the 1642 letter to August II, Andreae referred to Von Wense as the "Knight of Lüneburg," and explained that it had been with him that he collaborated to form the society described in the Image of a Christian Society and in opposition to the Rosicrucian one. Only careful readers, he informed the Duke, would understand the true meaning of the society of the Image. ${ }^{128}$

It is likely that the formation of this "Societas Christiana" never advanced beyond the planning stages, and that the members on the list were never actually recruited. ${ }^{129}$ First of all, Andreae included Hess among the society's prospective members, but Hess had already passed away in 1614 and could not have been a member of this society in 1620. But more importantly still, Andreae explained to Duke August II that their hopes for this society had been crushed by the damage and despair caused by outbursts of religious destruction, that is, by the Thirty Years' War-further suggesting that an implementation of the

123 On Sennert, see for example: Lüthy and Newman, "Daniel Sennert's Earliest Writings"; Clericuzio, Elements, Principles and Corpusles, 23-33; Hirai, Medical Humanism and Natural Philosophy, 151-172, and the references included there; Moreau, Eléments, atomes et physiologie, 244-313.

124 On Bernegger, see: Bünger, Matthias Bernegger: Ein Bild aus dem geistigen Leben Strassburgs zur Zeit des Dreissigjährigen Krieges.

125 On Schickard, Leibniz, and the calculus, see: Lehmann, "Schickard und Leibniz als Erfinder von Rechenmaschinen."

126 On this, see: Neumann, "Olim, da die Rosen Creutzerey noch florirt," 99-10o; Rublack, The Astronomer and the Witch, 234. On Schickard in general, see especially the articles included in Seck (ed.), Zum 40o. Geburtstag von Wilhelm Schickard. On Mögling, see sections 4.5 and 5.2 .

127 Gilly, Cimelia Rhodostaurotica, 68; idem, "Die Rosenkreuzer," 42-43; Brecht, Johann Valentin Andreae, 75. Earlier, Kienast mistakenly maintained that this translation was made by Besold: Kienast, Johann Valentin Andreae, 138-140.

128 Andreae, letter to Duke August II, 27 June 1642, in Gesammelte Schriften, vol. 6, 343-344.

129 On this, cf. Gilly, "Die Rosenkreuzer," 56. 
plans never saw the light of day. ${ }^{130}$ At any rate, at various stages of his life Andreae desired to establish a society that would respond to religious, societal, and academic abuses and would carry out the necessary reforms.

\section{The Reform of Religion, Politics, and Knowledge}

Andreae outlined this agenda for reform in several of his writings, especially in his Christianopolis where he described on numerous occasions the reformation of exactly the three fields he had named also in the manifestos, namely religion, politics, and knowledge. The text is not a call for reform in the same way as the manifestos are, but instead depicts an imaginary place in which these reforms have already taken place, (1) with an evangelical Christian religion; (2) realised in an ideal state; (3) where exceptional studies were offered.

According to Andreae's introduction to Christianopolis, Luther's Reformation had already wrought improvements in these three areas: religion had become more pure, it had brought positive effects on government, and had restored scholarship. ${ }^{131}$ Similarly to the manifestos, Andreae began by giving the impression that there was no need for radical reform. ${ }^{132}$ But tellingly, he remarked that un-Christian practices had crept into the institutions related to these three fields - the churches, courts, and universities—so that further reforms were required. ${ }^{133}$ In his introduction, Andreae continuously referred to this triad of institutions and the errors they promoted. He declared that their leaders pretended to be "religious, statesmenlike, and scholarly," but that in truth "the leaders of churches would acknowledge no simony, the leaders of politics no dishonesty, and the leaders of academia no ignorance."134 Their stubbornness is reminiscent of the Spanish scholars encountered by Christian

\footnotetext{
130 Andreae, letter to Duke August II, 27 June 1642, in Gesammelte Schriften, vol. 6, 343-344.

131 Andreae, Reipublicae Christianopolitanae descriptio, 7-8: "Ita invictus ille heros, D. Lutherus noster emersit [...]. Eluxit nobis purior Religio, indeque politiae administratio formata, \& literarum nitor redditus."

132 On the absence of radical reform and the support for the first renewed Churches and the Holy Roman Empire in the manifestos, see above, section 1.1.

133 Andreae, Reipublicae Christianopolitanae descriptio, 8-9: "Nam cum ad Christum nostrum, cujus nomen ferimus \& provitemur, formata nostra omnia esse debebant, pessima nostra indulgentia sit, ut a Mundanis nihil Christiani differant. Sive enim Ecclesias, sive Aulas, sive Academias intueamur, nuspiam absunt illa ambitionis, avaritiae, gulae, libidinis, invidiae, otij, \& alia vitia imperantia, a quibus vehementer abhorret Christus."

134 Ibid., 9: "Nostra simplicitas animadverti, qui, dum religiosi, politi, \& eruditi audiamus, qualibet rei umbra acquiescimus"; ibid., 10: "Cum Ecclesiarum Antistites nullam Simoniam, Politiae nullam improbitatem, Academiae nullam imperitiam agnoscerent, \& devotionis, probitatis ac literaturae moniti perduellionis accusarentur."
} 


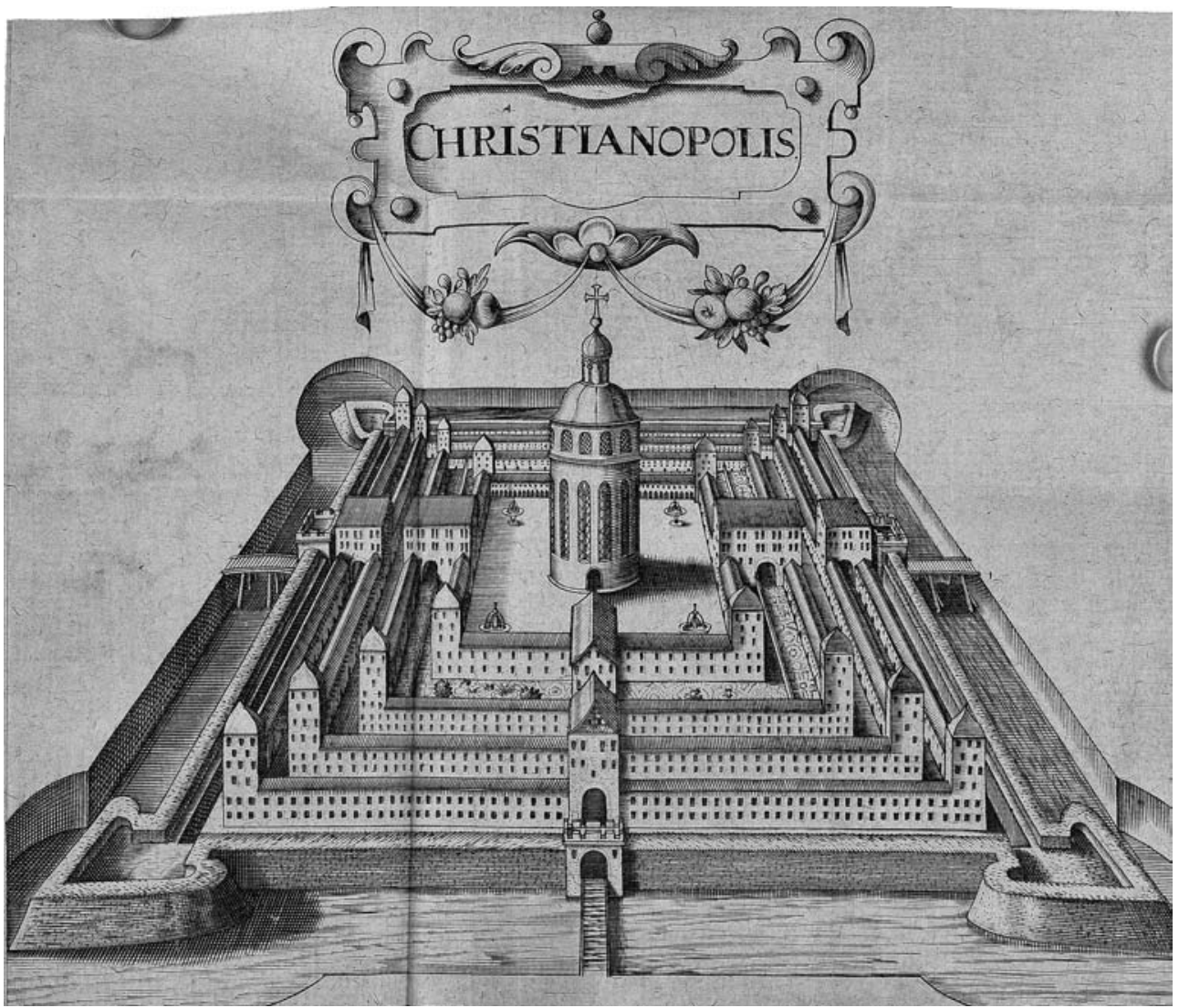

FIGURE 7 Johann Valentin Andreae, Reipublicae christianopolitanae descriptio, HAB Wolfenbüttel

Rosencreutz, who likewise clung to their mistakes and denied their ignorance, thereby avoided reform. ${ }^{135}$ Thus Andreae decried the flaws, immorality, and vices abounding within these institutions and the wickedness of their exponents. ${ }^{136}$ The three institutions were disgraceful, destructive, and corrupt. ${ }^{137}$

135 On these Spanish scholars, see above, sections 1.1 and 1.3.

136 Andreae, Reipublicae Christianopolitanae descriptio, 10: "Si credimus retorsionibus, tota Ecclesia fenestrata est, cui involare licet, ubi libet, \& intra aveolos susurrare: Respublica forum, ubi vitia emere \& vendere concessum; Academia labyrintus, ubi oberrare lusus est atque artificium." Cf. also ibid., 11.

137 Ibid., 12-13: "Quam turpiter enim ventris in media Ecclesia servitium, morum in medio fore dissolutio, ingenij in media literarum palestra, corruptela undique tituli sine re, prodigalitasque sine fine excusentur, imo elogijs ornentur, \& exponantur, non sine horrore cordati intuentur." 
Andreae lamented that the representatives of churches, courts, and universities were Christians in name, but not in behaviour, ${ }^{138}$ and in response he encouraged his readers to change their own conduct:

Because if conscience urges us to complain about the security of religion, the impurity of life, and the jokes of literature, what prohibits that we, at least within ourselves if others do not want it, pull out sins, plant virtues, and join ourselves closer to our Christ, whom we fear to be very far removed from our issues? 139

Immediately before this passage, Andreae discussed the Rosicrucian fraternity and referred to it as a "joke," a ludibrium. The ludibria mentioned in the passage above therefore possibly refer to the Rosicrucian manifestos, so that even while suggesting a reform of institutions and their representatives he made sure to dissociate himself from the enthusiasts that had contaminated his plans as laid out in the manifestos. ${ }^{140}$

Also in the main body of the text, which comprises one hundred chapters, Andreae frequently returned to this triad of religion, politics, and academia. As a counter-proposal to what he found in the real world, in this utopian novel he described an ideal community that lived on an imaginary island. The ship "Fantasy," on which an unnamed stranger was boarded, crossed the "academic ocean," but was shipwrecked. The storms at sea thrust the passenger off the ship, as a result of which he was stranded on the biblically named island of Capharsalama ("village of peace"). ${ }^{141}$ The stranger arrived in the city of Christianopolis, which he found so agreeable that he instantly decided that he wanted to live there. The stranded stranger described the role of money in corruption

${ }_{13} 8$ Ibid., 8-9: “[...] possemus omnino triumphare tot devictis hostibus, superstitione, dissolutione \& barbarie; sed nos clandestinae Diaboli insidiae affligunt, ut minus solidum sit gaudium, nomenque sinere ut plurimum relinquatur. Nam cum ad Christum nostrum, cujus nomen ferimus \& provitemur, formata nostra omnia esse debebant, pessima nostra indulgentia sit, ut a Mundanis nihil Christiani differant. Sive enim Ecclesias, sive Aulas, sive Academias intueamur, nuspiam absunt illa ambitionis, avaritiae, gulae, libidinis, invidiae, otij \& alia vitia imperantia, a quibus vehementer abhorret Chirstus; sed quibus nos delectamur maxime."

139 Ibid., 16: "Nam si nos conscientia urget, ut de religionis securitate, de Vitae impuritate, \& literarum ludibrijs habeamus, quod conqueramur, quid prohibet, quo minus in nobis saltem, si alij nolint, evellamus vitiosa, plantemus virtutes, \& Christo nostro propius iungamur, quem a rebus nostris remotißimum metuimus [...]."

140 Ibid., 16.

141 Cf. 1 Maccabees 7:31: "Nicanor realized that his plan had been discovered, so he left Jerusalem to meet Judas in battle near Capharsalama" (Good News Translation). 
in his home region, where humans "have sold Christian freedom to the Antichrist, natural freedom to the tyrant, and human freedom to sophistry." 142 This disapprobation aligns with the hope, expressed in the manifestos, of replacing the papal Antichrist with a new spiritual and political leader, and of replacing academic sophistry with genuine knowledge. The Rosicrucian brethren would have concurred with Andreae's conclusion that "as ignorance desired and imposed, hypocrisy has taken upon itself and has with violence usurped the patronage of religion, the tyranny of politics, and the sophistry of knowledge."143 In fact, Andreae explicitly referred to the Rosicrucians "in relation to this," who had, albeit "in jest," reacted to these lamentable circumstancesand he thereby implicitly affirmed that his basic reform ideals still pointed in the same direction as they had done when he wrote the Rosicrucian manifestos. ${ }^{144}$

In this utopian story, Andreae pits against the perceived decadence and dishonesty of his own time the perfect state of the institutions of his fictional, ideal community on the island of Capharsalama. He portrayed its admirable religion and politics, and expounded at length on the perfect sciences and studies of the Christianopolitans. Where the Rosicrucian manifestos had especially sketched the third pillar of their reformation in the domain of philosophy, so Andreae went to great lengths in depicting the studies of the Christianopolitans. ${ }^{145}$

Their learned endeavours were radically different from standard university practices of the time. The text explains how, before being admitted into the community, the shipwrecked stranger must submit to several interviews to determine his piety and modesty, and to assess whether he adhered to any group of religious fanatics, alchemists, or such imposters who falsely claimed to be members of the Rosicrucian fraternity. ${ }^{146}$ The studies in Christianopolis

142 Andreae, Reipublicae Christianopolitanae descriptio, 10o: "O venale genus humanum, quod libertatem Christianam Antichristo, libertatem naturalem tyrannidi, Libertatem humanam sophisticae vendidit."

143 Ibid., 11-12: "Atque ita Hypocrisis Religionis, Tyrannis Politiae, Sophistica literaturae patrocinium, volente ita \& imperante ignorantia, in se susceperunt \& violenter usurparunt."

144 Ibid., 13: "Hujus rei, post illa Theologorum seria, Fraternitatis cujusdam, mea opinione ludibrium, conspicuum edidit testimonium." On Andreae imitating the Rosicrucian fraternity, see: ibid., 15, as noted above, n. 101.

145 On Andreae's reform of the sciences, see: Brecht, "Kritik und Reform der Wissenschaften bei Johann Valentin Andreae," esp. 132-147.

146 Andreae, Reipublicae Christianopolitanae descriptio, 29-30: "Arrisit praefectus: \& ut haec Insula nihil importum habet, benigne monuit, ne ex ijs essem, quos civium communitas, apud se non ferret, sed ad sua remitteret, mendicantibus, circulatoribus, histrionibusve, quibus otium arrideat; curiosis, qui in insolitis scrupulentur; fanaticis, quibus nulla certa 
diverged not only from academia, but also from the false practices of fanatics and imposters, among whom Andreae did not include the Rosicrucians, but only those who falsely claimed to be members of their society. ${ }^{147}$ This suspicion of imposters is in keeping with the Fama itself, in which imposters are denied the right to receive responses from the Rosicrucian brethren; as well as with the Chemical Wedding, where imposters are barred from entry into the royal castle. ${ }^{148}$ It is noteworthy that also in the Chemical Wedding Christian Rosencreutz had to pass a test before being admitted into the royal palace. ${ }^{149}$

The stranded stranger in Christianopolis was tested on his knowledge of true and honourable studies. In the third and final examination, he was questioned about his knowledge of nature and the heavens, about which the stranger confessed to be ignorant. ${ }^{150} \mathrm{He}$ explained that he had spent much time, effort, and money on his studies when he was still at university, but had encountered much in Christianopolis of which he was ignorant. ${ }^{151}$ His acknowledgement of his lack of knowledge, despite his university training, was the reason that he was eventually admitted into the community. University practices on the other side of the academic ocean were incompatible with and incomparable to the ideal intellectual training of the Christianopolitans. After having been admitted, the protagonist introduced his readers to the city which-incidentally not unlike the portrayal of Rosencreutz's tomb in the Fama —included the mention of many measures of spatial dimensions. ${ }^{152}$

Christianopolis was not the only work in which Andreae rejected academia in general or university education in particular, while already in the manifestos he had deplored the prevalent practice of university disputations. ${ }^{153}$ Like Arndt, he explicitly distanced himself from scholastic book study and

pietas; ciniflonibus qui chymiam macularent; impostoribus, qui se Roseae Crucis Fratres mentirentur, \& similibus alijs literarum, humani atisque verrucis, quibus nunquam hujus Urbis inspectio bene cessisset." On the question of piety, see ibid., 30-32.

147 This is contrary to Brecht, who misreads this passage as being directed at the Rosicrucian themselves, rather than at those who falsely claimed membership, see: Brecht, Johann Valentin Andreae, 145.

148 Fama, 127; Andreae, Chemical Wedding, 31-32.

149 Andreae, Chemical Wedding, 31-42, esp. 41.

$15^{\circ}$ Andreae, Reipublicae Christianopolitanae descriptio, 32-34.

151 Ibid., 42-43: "De caetero mihi haec intuenti perpetua fuit animi exprobatio, qui tempore invitatus, sumptibus conductus, libris adjutus, nihil eorum didicissem, quae scire omnino deceret, \& naturae vultum, quae maxime blandiebatur, inexcusabile socordia neglexissem." The passage is about the study of metals and minerals.

$15^{2}$ Fama, 112-118.

153 Ibid., 123-124, cf. above, section 1.3. 
the followers of Aristotle. ${ }^{154}$ But also his Menippus (1617), which incidentally argued against the Rosicrucian fraternity, implicitly concurred by satirising academic teaching and notably the practice of disputations. ${ }^{155} \mathrm{He}$ voiced similar sentiments in his Turbo (1616), in which the eponymous main character (Turbo) had studied logic, rhetoric, and other academic subjects for over ten years, without gaining any noteworthy knowledge. And so Turbo turned to the study of the world, but became insatiably curious and lost himself in magic and alchemy (just like the imposters mentioned in the Fama, Chemical Wedding, and Christianopolis), and finally realised that the only meaningful knowledge was the knowledge that had its foundation in Christ. ${ }^{156}$

What was wrong with scholastic university practice was explained in no uncertain terms in Andreae's second Invitation:

Just as dubitation, disputation, and opposition have taken their origin from no one but Satan, so today it has no stronger and more assiduous promotor than Satan; and just as the world has nothing more splendid in the present time than the collations, disquisitions, and examinations of the most diverse sentences, so the Holy Spirit has nothing sadder and less manageable than the reluctant and disputing soul. Man himself has nothing more troublesome and dangerous in the moment of death but the doubts and objections of the flesh. ${ }^{157}$

Although he was surrounded by scholars, Andreae dreamt of an educational system that was profoundly different from the academic educational landscape he knew. Importantly, despite his emphasis on Christ as the source of all valid knowledge, his ideal education served not only the soul. In several of his writings, he promoted studies that he believed could contribute to

154 On Arndt rejecting book study and followers of Aristotle, see: Gilly, "Hermes or Luther."

155 Andreae, Menippus 24-25; Brecht "Johann Valentin Andreae," 288-289. On the text, see: idem, Johann Valentin Andreae, 111-120.

156 Andreae, Turbo; Van Dülmen, Die Utopie, 97-105. See also ibid., 105-107, on other writings in which the prototypical curious person is mocked because his curiosity leads him away from Christ. On Andreae and magic, see: Gilly, Cimelia Rhodostaurotica, 51-52.

157 Andreae, Invitationis ad fraternitatem Christi pars altera paraenetica, 55: "Sicut enim dubitatio, disputatio, oppositio, a nemine nisi Sathana initium sumpsit; ita neminem hodie quam Sathanam fortiorem diligentioremque habet promotorem: Sicut Mundus nihil hoc tempore quo se jactet speciosius habet, quam tot diversissimarum sententiarum collationes, disquisitiones, examina; ita Spiritus sanctus nisi animam reluctantem, disputantemque infelicius ac intractabilius nihil habet. Ipse homo in mortis articulo, nisi carnis dubia \& objecta nihil molestius, \& periculosius." 
the improvement of life. The hierarchical society of the Image, for example, which Andreae had drafted with the support of Von Wense, counted twelve faculties or colleges which had as their unified aim the curing of evil and the improvement of the good. ${ }^{158}$ At its head could be found a German leader, which we now know was supposed to be Duke August II, a most illustrious man whose "secret council" consisted of one Fellow of German origin from each of the twelve faculties. In this regard, the Image is similar to the manifestos' description of the Rosicrucian order, which was established also by a German founder, Christian Rosencreutz, whose secret brotherhood was located in German regions and was dedicated to the improvement of earthly matters.

Three of the Fellows described in the Image were higher in rank than the others, namely those directing sacred things, virtues, and letters. ${ }^{159}$ Fellows from the other nine faculties included a theologian, politician, physician, censor (magistrate), historian, mathematician, philosopher, economist, and a philologist. ${ }^{160}$ With the inclusion of a censor, politician, and economist the society represented not merely a learned academy, but rather, like that in Christianopolis, a community. The individual objective of all scholars contributed to the understanding of creation, as their collective aim was a comprehensive understanding of reality. The similarity to the Rosicrucian fraternity is evident, which also had as its explicit aim the understanding of the entire universe.

The society in the Image was to represent a true Christian, German gymnasium. ${ }^{161}$ For Andreae, these studies had a Christian objective, as they found their purpose in a Christian society and were directed towards the service of Christianity. Despite its lack of pietist characteristics, the Confessio also qualified the studies and philosophy of the brethren as Christian, because their philosophy was "above all consistent with that wonderful book, the Bible."162 They claimed that "the nearest and most similar to us are those who make the Bible their rule of life, the summa of their studies, and the compendium of the

158 Andreae, Christianae societatis imago, $\mathrm{B}^{\mathrm{r}}$.

159 Ibid., $\mathrm{A} 4{ }^{\mathrm{v}}-\mathrm{A} 5^{\mathrm{v}}$ : "Caput societatis ex Germaniae Principibus vir Pietate, Probitate, \& literatura Illustrissimus est, qui sub Secretioris Consilii Collegas duodecim habet, omnes insigni aliquo Dei donario cinspicuos. E quibus tres eminent, Unus Sacrorum, Alter Virtutum, Tertius Literarum Antistites [...]. Omnes Germani sanguinis [...]."

160 Ibid., $\mathrm{B} 2^{\mathrm{r}}-\mathrm{B} 8^{\mathrm{v}}$.

161 Ibid., B8 ${ }^{\mathrm{v}}-\mathrm{C}^{\mathrm{r}}$.

162 Fama, 123-124: "unser Philosophia ist nichts newes sondern wie sie Adam nach seinem Fall erhalten und Moses und Salomon geübet [...] besonders wo das grosse Wunderbuch die Biblia concordiret." Cf. above, pp. 83-84. 
entire world $[. .]$.$" - a sentence that reappeared in the Sheath. { }^{163}$ The Rosicrucian fraternity was inherently Christian in nature, and its religion, studies, and philosophy were formulated accordingly. The Fama invoked the words "Jesus mihi omnia," "Jesus is everything to me,"-a phrase that was to reappear verbatim at the end of several of Andreae's other works, such as his Turris Babel, and at the end of the main part of his Menippus in the formula "Jesus nobis omnia" ("Jesus is everything to us"). ${ }^{164}$

The resemblances between the philosophy of the Rosicrucians and the studies of Andreae's fictitious societies are even more evident in his Christianopolis. Andreae located a college at the centre of his imaginary city. In keeping with the triad of religion, politics, and knowledge, he placed there a theologian, a judge, and a scholar-which indicates the essential nature of their roles. ${ }^{165}$ This crucial place was also reserved for the city's archive, library, and printing press, which ensured that important works were stored, read, and distributed. ${ }^{166}$ In Christianopolis, the study and education of both boys and girls took place in eight lecture theatres, where they could practice many different arts and sciences, ranging from alchemy to theology, and from astronomy to theosophy. These studies were practised in a way that distinguished itself favourably from conventional university education. While neither the Fama nor the Confessio had expounded upon the structure of the Rosicrucian society, its educational programme, and the objects of its teaching, the studies performed within Christianopolis' lecture theatres might indicate the direction in which the young Andreae imagined a pedagogical reform in the days of writing the manifestos.

Alchemy had played an ambivalent role in the Fama and Confessio. While the manifestos rejected false alchemical practices along with the use of pictures, they depicted transmutational alchemy as a "parergon," a secondary activity, of the Rosicrucian brethren, who sought to decode nature's secrets. Unlike early modern university teachers, some citizens of Christianopolis dedicated their entire lives to the practice of alchemy-for which reason also Sennert, who was among the first to combine university teaching with alchemy, must have

163 Confessio, 57-58: "ita proximi ii, et maxime similes nobis, qui una Biblia suae vitae Regulam, suorum studiorum summam, mundique universi compendium faciunt [...]." Cf. Appendix.

164 Andreae, Turris Babel, 72: "Jesus mihi omnia"; Andreae, Menippus, 183: "Societas nulla extra Fraternitatem Iesu, finis nullus praeterquam aeterna cohabitatio Iesu: ita Jesus nobis omnia erit in omnibus, quo in uno Acquiescemus." Cf. Fama, 114.

165 Andreae, Reipublicae Christianopolitanae descriptio, 66-67. These officers and their wives had important duties, see: ibid., $76-90$. Their wives were characterised by conscience, understanding, and truth, respectively.

166 Andreae, Reipublicae Christianopolitanae descriptio, 92-98. 
been a suitable candidate for Andreae's "Societas Christiana" of 1620 . As in the manifestos, the Christianopolitans' foremost objective was not the creation of the philosophers' stone or of gold, but the study of the world. Alchemy, in Christianopolis, was practiced in order to investigate all aspects of creation experimentally, including the animal, vegetable, and mineral worlds. In the alchemical laboratory, the workers learned "to master fire, to employ air, to estimate water, and to test the earth." Here, "heaven is married to the earth, and the divine mysteries impressed on the earth are also discovered." 167 In alchemy, they studied and combined earthly and divine matters, disclosing hidden patterns.

The use of alchemy was not merely experimental and epistemological. The alchemical laboratory in Christianopolis also served the human race in medical issues. In the footsteps of Paracelsus and in accordance with the spagyric medicine alluded to in the manifestos, elements were refined, concentrated, and combined for healing purposes. ${ }^{168}$ The Rosicrucian manifestos rejected traditional Galenic practices and praised alchemy as a gift of God and as the highest medicine of the world. ${ }^{169}$ Similarly, in Christianopolis alchemical medicine is viewed as a "gift of God."170 But this utopian narrative also reflected other innovations in medical studies. The new study of anatomy, particularly that of Andreas Vesalius, must have inspired Andreae's choice to include in his Christianopolis an anatomical laboratory, which was intended for the dissection, study, and improvement of the human body. ${ }^{171}$ Similarly in the Christian Mythology, Andreae described an imaginary anatomical study of Hess' spiritual body, notably by Vesalius, who establishes that Hess was a healthy and pious person who would have been immortal were he not, like all human beings, affected by original sin. ${ }^{172}$

According to Andreae's popular fictional story, the Christianopolitans could study the phenomena of heaven and earth in the mathematical theatre and the physical theatre, respectively. ${ }^{173}$ They admired the work of Tycho Brahe, as well

167 Ibid., 100-102: "Hic metallorum, mineralium, vegetabilium, animalium etiam vires examinantur, purgantur, adaugentur, combinantur, in humani generis usum \& sanitatis commodum. Hic Coelum Terrae maritatur, \& Divina mysteria etiam terrae impressa reperiuntur, hic ignem regere, aerem adhibere, aquam aestimare, terram experiri addiscitur."

168 Ibid., 100-102.

169 Confessio, 58-59, cf. above, pp. 122, 13 o.

170 Andreae, Reipublicae Christianopolitanae descriptio, 168: "Medicinae subtilitatem, methodum, rationabilitatem nemo facile explicabit: fatendum est, Dei insigne donum esse."

171 Ibid., 102-105.

172 Andreae, Mythologiae Christianae, $22 \mathrm{ff}$.

173 Andreae, Reipublicae Christianopolitanae descriptio, 105-107, 111-113. 
as the use of instruments such as the telescope with which the heavens could be observed in more detail and explained with more accuracy. ${ }^{174}$ In the Fama, such celestial phenomena had prophetic astrological relevance, owing their origins, at least in part, to Hess' preoccupations. But also in Christianopolis, in the fifth lecture theatre, the citizens studied the influence of celestial phenomena on earthly affairs and what "the heaven communicates to the earth."175 The earth, they believed, was under the influence of the stars. ${ }^{176}$ Yet, "the routine of the stars is annotated, out of greater admiration for human curiosity than out of human safety."177

The heavens communicated their influence, but one should preferably submit oneself to the spiritual heavens and the divine plan. ${ }^{178}$ Besides studies of the natural world, the Christianopolitans, like the Rosicrucian brethren, studied divine reality. According to the Rosicrucian manifestos, divine secrets were conveyed through creation; human beings could study God's celestial portents and the characters He had kept hidden in nature and in living beings. ${ }^{179}$ Thanks to God's grace, one could acquire knowledge of the Son and of the universe's harmony through the microcosm that was pitched to the same tone and melody as God. ${ }^{180}$

Likewise, in the third lecture theatre in Christianopolis students had the possibility of studying divinity and of acquiring divine knowledge, notably through the study of creation and by means of arithmology. ${ }^{181}$ Students were taught in "mystic numbers" and studied the numbers and measures of creation so as to

174 Ibid., 110: "Non recensebo hic instrumenta, quoniam ex generosissimi Tychonis Brahei descriptione fere omnia liquent: accessere pauca alia, \& in is telescopium nuperum inventum elegantissimum." Andreae adhered to the Copernican worldview, according to which the earth is in motion, and also assumed that there was life on other planets; see: ibid., 142: "Huic plurimum tribuunt Christianopolitani, nec sibi metuunt, ne terraemotu excidant, aut a novis Astricolis deturbentur."

175 Ibid., 144: "In hoc eodem Astrologia se offert, multis nominibus estimanda. Nam quid Terra Coelo debeat, quid Coelum Terrae cummunicet, ij experiuntur, qui utrumque patiuntur." Elsewhere, Andreae rejected astrology as devilish; see: Brecht, Johann Valentin Andreae, 38 .

176 Andreae, Reipublicae Christianopolitanae descriptio, 144: "[...] inter utrumque terra se coelo subjectam fatetur. Solis \& Lunae vires magis in evidenti sunt [...]."

177 Ibid., 144: "Hinc astrorum regimen annotatum est, majore curiositatis humanae admiratione, quam securitate."

178 Cf. ibid., 144: "Certe animum, ut ut corporis carceribus clausum, nemini subiiciunt, nisi Deo, ac soli Deo."

179 Confessio, $56-57$, cf. above, p. $82 \mathrm{ff}$.

18 o Fama, 123-124, cf. above, sections 1.3 and 2.4.

181 On arithmology, cf. Brach, "Mathematical Esotericism." 
acquire knowledge of God. ${ }^{182}$ According to Andreae, this arithmological study was a Christian interpretation of Cabala, which should be studied carefully and which ultimately depended upon God's revelation. ${ }^{183}$ The students observed divinity within creation, because

above all, God placed His mysteries for us in His fabrics and typical structures, so that we may disclose the length, the breadth, and the depth of divinity by means of the Key of David, and we may perceive the presence of the Messiah through all things. ${ }^{184}$

From the measures of the universe, the measures of God could be deduced. 185 The universe had therefore to be studied and measured in order to understand God's mysteries and to observe Christ's presence within it by means of the key with which one could, like Christ, unlock and reveal divine secrets. ${ }^{186}$ Hess, when investigated by the theological faculty of the University of Tübingen, also briefly referred to the Key of David, and explained that it could be used to understand the secret chronology hidden in the Bible. ${ }^{187}$ Like the Rosicrucians in the manifestos, Andreae and Hess both had recourse to the clavis universalis, by means of which they, as with the clavis Davidica, probed into the hidden reality beyond the visible exteriority of nature.

The Christianopolitans studied God specifically in the second lecture theatre of metaphysics and theosophy, and the divine secrets they were taught there agreed with the ideas expressed in the manifestos. In the second lecture theatre the wonders of God were studied, about which the stranger commented: "How foolish we are, that we prefer Aristotle to ourselves, that we embrace that little man instead of the marvels of God, which put him

182 Andreae, Reipublicae Christianopolitanae descriptio, 134: "De numeris mysticis [title]. Sed etiam altius ascendunt, quibus anni majores sunt. Habet enim Deus numeros suos \& mensuras: quae contemplari hominem decet."

183 Ibid., 136: "circumspectos oportet in hac Cabala esse, \& conjecturarum temperantes: cum in praesentibus laboremus, in praeteritis caligemus, futura vero Deus uni sibi reservarit, paucissimis, ac maximis intervallis communicanda."

184 Ibid., 135: "maxime vero in fabricis suis \& typicis structuris nobis mysteria sua deposuit, ut per Clavem Davidicam, longitudinem, latitudinem, \& profunditatem Divinitatis recludamus, atque Messiam per omnia diffusum annotemus [...]."

185 Ibid., 134-135.

186 Cf. ibid., 135-136: "Sufficiat nobis, Christum nobis omnibus ea omnia explanasse, quae ad corrigendam, tolerandamque vitam faciunt, quae illuminant non omnes invadamus, nisi Christi jubar praeeat, \& ad interiora occlusa vocet." For the Key of David, see: Revelations 3:7 and Isaiah 22:22.

187 UAT, 12/17, nr. 39, question v; UAT, 12/17, nr. 42; Brecht, "Chiliasmus in Württemberg," 29. 
[sc. Aristotle] to shame"-and which thereby shame the entire scholastic university enterprise. ${ }^{188}$ In metaphysics, the citizens lifted themselves up to the primum ens, the first being, God. ${ }^{189}$ In theosophy, they were instructed by God himself: "Where nature ends, here [theosophy] begins, and taught by the supreme divinity, it religiously guards its mysteries."190 The students of theosophy could rise up, free themselves from worldly attachments, and come closer to God who revealed Himself not just through His Word but in manifold ways. ${ }^{191}$

The idea that one was able to acquire adequate knowledge of the world and of God even after the Fall — which implies that one is not affected by original sin as thoroughly as Augustine or Luther would suggest-was an important implication of the Rosicrucian reformation of the divine and the human. ${ }^{192}$ In his Christianopolis, too, Andreae seems to suggest that the consequences of the Fall could be reversed so that the citizens could again fully comprehend the Creator and His creation. While reading from a tablet about the religion of the Christianopolitans, the stranded protagonist of the story reads that "we believe $[\ldots]$ in the restitution of the dignity taken away through the Fall of Adam." ${ }^{193}$ This belief is an echo of the claim made in the Confessio that "God has declared truth, light and dignity to return to the world, which would not long afterwards be destroyed: such things as he had ordered to move from Paradise together with Adam and to temper man's misery." 194 The mention of "dignity" is noteworthy, and presumably indicates that man had regained his original purity in the image of God. With such claims, Andreae incidentally violated the

188 Andreae, Reipublicae Christianopolitanae descriptio, 129: "Imprudentes nos qui Aristotelem nobis praeferimus, homuncionem nobiscum, non Dei admiranda amplectimur, quae illum pudefaciunt."

189 Ibid., 127: "Alij in hoc loco Metaphysicam audiunt, scientiam, quae ab omni se concretione abstrahit, \& ad prima entia subvolat, condignam utique homine, cujus ingenium ad id natum, ut terrenis se subtrahat. Hic verum, bonum, pulchrum, unum ordinem, \& similia contemplantur [...]."

190 Ibid., 129: "Ubi natura desinet, haec incipit, \& a superno numine edocta, mysteria sua religiose servat."

191 Ibid., 129: "Momento se pandit Deus, diu adytis suis involvitur, semper optimus, raro visibilis; Sunt tamen infinita ejus revelata, in quibus deliciari cujusvis vere Christiani est."

192 Cf. above, section 1.3.

193 Andreae, Reipublicae Christianopolitanae descriptio, 71: "Credimus [...] dignitatisque per Adami lapsum ablatae restitutionem."

194 Confessio, 53-54: "Illud itaque unum nobis confirmandum est, Mortales, Deum mundo haud longe post interituro, reddendam veritatem, Lucem et dignitatem decrevisse: qualia cum Adamo Paradiso emigrare, \& hominis miseriam condire jussit." On this passage, see above section 1.3. 
interpretation of human nature after the Fall as expressed by his grandfather when he co-authored the Formula of Concord.

According to the tablet that the stranger read in Christianopolis, the restitution of dignity had already taken place thanks to the crucifixion and resurrection of Christ: "We believe that by His life, suffering, and death, He satisfied the justice of God, and that the compassion of God has been deserved [...] and so the dominion of sin has been crucified, destroyed, and buried."195 Thanks to Christ's sacrifice, the triumph of sin has come to an end and the possibility of perfection has been restored, as "the kingdom of Hell and the poison of death are destroyed" - a passage quite in keeping with the Rosicrucians' contemplations regarding the prolongation of life, but in opposition to Lutheran orthodoxy. ${ }^{196}$ Whilst Christ's sacrifice had for long permitted the possibility of a restoration of Adamite conditions, it was also necessary to engage in the right moral and scientific conduct in order to benefit from this possibility. It was one thing to be reconciled with God, but yet another to know how to live a long and healthy life like the old Jewish Patriarchs_-but this was now possible for the Christianopolitans.

Hess had held similar views. Although he had answered his Lutheran investigators that sin would not be entirely eliminated in the future earthly age of the Holy Spirit, he expected the attainment of complete and perfect knowledge in that time. ${ }^{197}$ Andreae's belief in earthly perfection and Hess' promise of perfect knowledge specifically in a future age are both encountered in the Rosicrucian manifestos.

In other texts, Andreae also emphasised that a perfect restitution of the body and perfect knowledge were possible. In his first Invitation, for example, he revealed that the members of a fraternity, bound through Christ and unattached to the world, could come to perfect knowledge not only of oneself and the world, but also of God:

For how long are we summoned, invited, and admitted elsewhere? Namely to that place where we could know God, ourselves, and the machine of the world more fully, and call everything by its true name, discern it by its true colours, and distinguish it by its sounds: we distinguish

195 Andreae, Reipublicae Christianopolitanae descriptio, 71: "Credimus, Vita ejus Paßione \& morte justitiae Dei satisfactum, \& misericordiam promeritam [...], indeque peccati dominium crucifixum, peremptum \& sepultum."

196 Ibid., 71: "Credimus inferni regnum, mortisque venenum destructum, \& Resurrectionis victoria securitatem nobis sub Dei cura redditam." Cf. above, pp. 159-16o.

197 UAT, $12 / 17$, nr. 38. 
with eyes, illuminated by God, the happy from the unhappy, the fruitful from the poor, the eminent from the dejected, in retrograde, that is, in the divine order. ${ }^{198}$

In other words, those members could acquire knowledge of God and His creation in this earthly life and come to an understanding of the "machine of the world" - a term also invoked in the manifestos — as was once possible for Adam in Paradise. ${ }^{199}$ Just as Adam named the creatures according to their nature, in the Invitation the true names became discernable, while in the Confessio a new language was used to express the true essences of things. ${ }^{200}$ In fact, Andreae claimed that one could on earth live in spirit as if already in the New Jerusalem:

Thus what is this, that we lose if we lose the world? [...] We will have a small piece of earth; the wide space of heaven awaits us. We will live in the people's temple, but we will soon be citizens of this Jerusalem constructed from pearls: we will be confined in a small space, but in our minds we will walk in paradise. ${ }^{201}$

This passage of the first Invitation shares certain notable similarities with the views of Paracelsus, who also identified the Paradise of Genesis with the New Jerusalem of the Book of Revelation. ${ }^{202}$

198 Andreae, Invitatio fraternitatis Christi, 40-41: "Nos vero quam longe aliorsum vocamur, invitamur, admittimur? Scilicet illuc ut \& Deum, \& nos ipsos \& Mundi machinam, plenius agnoscamus, quodlibet vero suo nomine appellemus, suis coloribus discernamus, suis sonis dijudicemus: felicem ab infelice, divitem a paupere, sublimema $\mathrm{b}$ [sic] dejecto, retrogrado, id est Divino ordine, oculisque a Deo illustratis dignoscamus."

199 Confessio, 52: "sane cuicunque Magnas illas Dei litteras, quas Mundi machinae inscripsit $[\ldots]$ intueri, legere $[\ldots]$ concessum." Cf. above, p. 68

200 Confessio, ${ }^{6-} 57$, see above, p. 9 off.

201 Andreae, Invitatio fraternitatis Christi, 78-79: "Quid est igitur illud, quod amittamus si Mundum amittimus? [...] Terrae exiguum possidebimus; at Coeli lata spatia nos expectant; aedes plebeias inhabitabimus; sed Hierosolymae illius ex margaritis constructae cives mox erimus; In angusto conclusi erimus, sed mente Paralysum [sic] inambulabimus." In other versions, "Paralysum" is replaced by "Paradysum," cf.: Andreae, Gesammelte Schriften, vol. 6, 140. According to Revelation 21:21, the New Jerusalem had twelve gates: "And the twelve gates were twelve pearls: every several gate was of one pearl: and the street of the city was pure gold, as it were transparant glass." Cf. also: Andreae, Reipublicae Christianopolitanae descriptio, 21, where he suggests that the text of the Christianopolis reveals the way towards heaven.

202 On Paracelsus' view, see above, p. 110. 
As far as the central element of the manifestos is concerned, that is, the call for a general reformation, the similarities with Christianopolis are striking. Admittedly, Christianopolis does not call for change, nor does it present a reform programme. As Andreae remarked in his introduction, he was disappointed by the responses the Rosicrucian manifestos had induced. But in the introduction as well as in the body of the text, he continued to criticise the contemporary state of affairs within the three areas for reform already identified in the manifestos - religion, politics, and knowledge. He thereby suggested that despite Luther another reformation was required, and he drew on notions antithetical to orthodox Lutheranism - an important facet of his thought given that he was a Lutheran deacon at the time of writing these tracts, and that in recent scholarship Andreae has been depicted as a faithful Lutheran. ${ }^{203}$ Aspects once related to the general reformation of the Rosicrucians reappeared in this utopian narrative and partly also in other stories drafted by Andreae. What the manifestos had called for in a non-programmatic way is realised in Christianopolis: there, the citizens studied the divine and the human, nature and God, in lecture theatres and institutions set up for that purpose; and the successful restoration of long-lost dignity before the end of history is quite in keeping with the contents of the Rosicrucian manifestos. In effect, Christianopolis represents an ideal community that seems to have successfully undergone the Rosicrucians' reformation.

Both the brethren of the Fama and the stranger of Christianopolis petitioned for their readers' responses. The Fama called for people to examine their own arts and to communicate their findings; the stranger, after having introduced readers to Christianopolis, expressed his hope that they would visit the city themselves and communicate their own findings about the studies conducted in Christianopolis. ${ }^{204}$ Only the Fama met with a significant number of answers, no doubt because readers would rather embrace a reformation to which they

203 Brecht, Kirchenordnung und Kirchenzucht in Württemberg vom 16. bis zum 18. Jahrhundert, 59-6o, for example concludes that even though Andreae cannot be regarded as a scholastic theologian and that he aimed to reform religion, nonetheless "[d]aß Andreä auf dem Boden des orthodoxen lutherischen Bekenntnisses stand und stehen wollte, dürfte mit all dem Vorhergehenden bewiesen sein [...]." His distance from university theology "beweist nur, daß Andreä geistig schon zu einer späten Zeit der Orthodoxie gehört, nicht aber, daß er sich von ihr losgesagt hätte." Cf. Montgomery, Cross and Crucible, vol. 1; Edighoffer, RoseCroix et société idéale, 2 vols.; Wels, "Die Frömmigkeit der Rosenkreuzer-Manifeste."

204 Andreae, Reipublicae Christianopolitanae descriptio, 167: "Atque ita rudi stilo percurri, quicquid in Auditoriis Christianis mihi est commenstratum. Quod utinam nihil de mea balbutie, forsan \& oblivione haberet! sperarem utique si non omnia, imo si pauca etiam, aliqua tamen pio \& Christiano lectori placitura, vel sane datura animum, ut Christianopolim quispiam adiens, certiora \& exactiora his experiatur: quae si eodem candore, 
felt they could contribute and from which they could benefit, than respond to a text that was obviously fictional.

\subsection{Paracelsian Motivation}

Andreae's views are evidently incorporated in the manifestos, but Hess' stamp on the manifestos should not be understated, because his contribution was not limited to the chiliastic interpretation of history and the apocalyptic figures that played a role in epochal times. He was also the source of the brethren's regard for Paracelsus and their promotion of Paracelsian views. There is no comparable esteem for Paracelsus to be found in Andreae's writings, apart from a few instances such as in his Menippus, where Andreae suggests combining Galenic and Paracelsian medicine. ${ }^{205}$ In their explicit praise for the medical reformer, the manifestos seem to reflect particularly Hess' aspirations. Hess had studied Paracelsus' writings and had worked as a Paracelsian physician for many years, using his alchemical knowledge in the preparation of cures. In his obituary, Andreae described Hess as a follower of Paracelsus. ${ }^{206}$ In German lands, Hess was known as one of the foremost Paracelsians. ${ }^{207}$ Because of his various views and practices, to Hess befell the unfortunate fate of being investigated not only for his Joachimite views by Tübingen's Faculty of Theology, but also for his Paracelsian practices by that university's Faculty of Medicine.

The investigations Hess was forced to undergo spanned the period from 1599 until 1613, the year before his death. In an official handwritten report of the medical faculty, dated 1599, the professors complained about Hess' medical practice. ${ }^{208}$ Physicians and apothecaries were supposed to comply with the medical statutes of the university, and as a corollary, the practice of medicine without the necessary academic qualifications was forbidden. ${ }^{209}$ The

eademque mecum libertate communicaverit, illorum certe, quorum id commodo fiet, sed meam etiam, quod juverit, \& emendarit, gratitudinem maximam promerebitus."

205 Idem, Menippus, 274. Cf. also: Brecht, "Kritik und Reform der Wissenschaften bei Johann Valentin Andreae," 136-141.

206 Andreae, Tobiae Hessi Immortalitas, 57-58. On this, see also: Gilly, Cimelia Rhodostaurotica, 47; idem, "Die Rosenkreuzer," 47-48; Brecht, Johann Valentin Andreae, 34.

207 Ulrich Bollinger had written at the end of Croll's Basilica Chymica about Hess: "Ille prius rigidi perplexa volumina iuris, Nunc Opus evolvit, Rex Paracelse, tuum"; see: Gilly, "Die Rosenkreuzer," 47.

208 For a brief discussion of this report, see also: Brecht, "Johann Valentin Andreae," 281-282.

209 UAT, 20/3a (1599): "Ferners und zum anders, ob wol in unsers gnadigen Fürsten unnd Herrn ordination, die doctores der Leibartzneÿ belangendt, Görblich [sic] verbotten, das 
professors took additional measures to protect their practice by condemning the use of medical theories other than those taught at the university. ${ }^{210}$

Hess, who had not graduated in medicine but in law, but was working as a Paracelsian physician, obviously did not meet these demands. He was seen as a "student of Paracelsus" who practiced alchemy and hoped in vain to make gold, losing much money. ${ }^{211}$ And, so the professors commented, "as all alchemists finally do, for the sake of making up the harm he had suffered he delved into medicine."212 Hess combined the alchemical art with his practice as a physician, ignoring the established practices. He was furthermore accused of having "communicated his allegedly Paracelsian cures" only to make his name greater among his well-placed clients. ${ }^{213}$ The report complains that he trained his own students in Paracelsian medicine and criticised the traditional medical treatment and its accompanying cures. ${ }^{214}$ Hess, who seems to have been a successful practitioner, thus became a threat to the medical establishment. The professors, displeased by his successes and his rejection of traditional medicine, deemed his cures "very dangerous" and denounced Hess for "selling himself as an ordinary physician." 215 They warned their students against Hess, but in their conclusion they did not press any formal charges against him. ${ }^{216}$

im ganzen Fürstenthumb kainer, der sich für ain Medicum Außgebe neben anders ordinarijs Medicis practiciren solle."

210 Ibid.: "[...] in unnsern Statutis capite De Decani officio einem Jeden Facultatis nostrae decano in seinens Jurament eingebunden ist, ut nulli medendi rationem in hoc oppido exercere permittat, qui in Universitate Scholae huius insignia doctorea non consecutus sit etc."

211 Ibid.: "[...] hat sich fürs erstehens ein gutte Zeitt hero Tobias Heß Juris prudentiae Doctor, vel Alchÿmista potius imbij illius Paracelsi discipulus herfür gethon, und nachdem Ime sein Goldtmachen nicht gerathen wollen, dardurch er doch viel Gelts onworden."

212 Ibid.: "[Er] hatt wie alle Alchemisten entlich pflegen, zu etwas ergötzlichkeit seines erlittenen schadens sich uff die Medicin begeben."

213 Ibid.: "Er [hat] seine vermainte pharmaca Paracelsica vergebenlich mittgetailt, Wölchs wir auch desto weniger geachtet, biß wir nhun mer Im Werck gnugsam spüren unnd erfarren wissen das er durch solches allain Ime ain namen unnd zulauff zu machen sich listiglich beflissen. Dann er ietzundt nicht nuhn allain die seinigen, sonder meniglichs, unnd bevorab hoches Laudt personen, nicht one worrtlichen schaden (wie solches nuhn zuvil offenbar und mit laidigen exempels wol zu erweisen ist)."

214 Ibid.: "Ja auch seine aigne discipulos annemet, dargegen unsere Medicam doctrinam und remedia, per tot seculorum sapientes approbata, et huc usque in omnibus bene constitutis Academijs et Rebuspub conservata (damit er desto höcher unnd allain für gelert angesehen werde) fälschlich beÿ Jederman verclainert unnd verachtet."

215 Ibid.: "Leider unsers gnedigen fürsten unnd Herrn ordnung seine Medicamenta Periculosissima vom Gauß umb uberschwencklichen Werth ußgibt, uff die practickh ußneuttet, consilia ußshreibet [sic], und in summa sich allerdingt für ainen Medicum ordinarium vendirirt."

216 Ibid. 
A second investigation followed ten years later, in 16o9. The professors appealed again to their statutes and referred to the 1599 report. Again they argued that Hess did not know his profession because he had no degree in medicine and because his cures were dangerous. ${ }^{217}$ But this report was markedly more negative about Hess' practice as a Paracelsian physician than the first one. The professors agreed with the previous report that Hess' recipes and cures were harmful, because they considered him an inadequate physician without any formal training. ${ }^{218}$ But this time his procedures were deemed "magical, devilish, and blasphemous." 219 Once the charge of blasphemy had been pronounced, Hess' medicine became also a religious issue, which called for a severe intervention as it threatened Tübingen's orthodox Lutheran tradition. By promoting "Paracelsian arts," Hess was seen to have installed himself in the movement of the Paracelsians that challenged not only the medical faculty but, according to the report, also the "higher faculty" of theology. 220

The medical professors inserted Hess into their larger argument against all dissenting "sects," whether belonging to the Paracelsian, alchemical, or "empirical" currents, and against all other "novatores" who deviated from school medicine and its canon. Any art practiced without the necessary academic qualifications was seen to belong to a new and strange philosophy and was therefore considered dangerous. ${ }^{221}$

The Tübingen physicians would have found their worst fears confirmed by the Rosicrucian manifestos, which similarly promoted Paracelsian and Her-

217 UAT, 20/12 nr. 5 (1609).

218 Brecht, "Johann Valentin Andreae," 282.

219 UAT, 20/12 nr. 5 (1609): “[...] unnd könden [...] beÿ hohen schuelen Paracelsica medicationes oder seiner scriptorum commendationes \& lectiones nicht gedultet werden, dann was für magische, teufflische, gotslästerliche sachen nach seinem ungereimbten medendi methodo, diser Paracelsus [...] hinderlaßen."

220 Ibid.: "Und ist gewiß, dass der Teuffel ein feind aller ORdnung und Schuelen, aber ein hurtiger Promotor seiner [Paracelsus'] Künsten, nicht nuhr unserer, sondern auch höherer FAcultet Zerrittung volrangst damit auströwet unnd gesuchet, wie dann ungereumbte sectierische Paracelsisten, fremder Theologi nach ihres Meisters deß Paracelsi weiß, vor andern sich vielmahls haben gelustet laßen."

221 See ibid.: "Darumb dann auch baÿ andern wolgestallten Universiteten, Inner oder außer Deutschlands, wo man gleich solcher chÿmicastrorum unnd empiricorum inn umblichgenden orten [...] dieselbige oder ihr artzneÿ in eo loco nit geduldet werden"; ibid.: "Dann auch ëbe deß offtgemelten statutis gemäß ÿede Facultet ihre besondern assignierte authores, unnd medicae facultatj allen Hippocratis unnd Galeni Scripta medica zue docieren befohlen/ könden wir nicht sehen, zum waß ersprießlichem End, nova illa Paracelsica \& empirica medendi ratio uns passieren zuelaßen möchete zuegemuert worden. Dann unsere alte weise vorfahren nicht weniger hirns gehabt alß unbedachtsam Novatores, unnd wol gewust." 
metical arts. Hess' combination of Joachimite expectations and Paracelsian doctrines left its clear mark on the manifestos. After all, in Hess' mind, religion and natural philosophy were so closely related because through the study of nature God could be observed - an idea later represented in the manifestos. ${ }^{222}$ His philosophy involved a combination of theological and medical endeavours, while neglecting the discipline of law in which he had been trained. This was quite in keeping with the manifestos' statement, also copied in the Sheath, that "[p]hilosophy includes much of theology and medicine, but little of law."223 It seems evident that the manifestos' apocalyptic expectations and Paracelsian impetus came from Hess rather than from Andreae.

\subsection{Concluding Remarks}

Andreae combined the piety of Arndt with a strong desire to change society and its religious, political, and educational institutions. He distanced himself from the Rosicrucian furore, of which he was the cause, so as to protect his name from what had become a proposal that, in his view, had gotten out of hand. He seems to have been singularly disheartened by the vociferous and fanatical mob that clamoured for membership of the fraternity - as he unambiguously pointed out in his second Invitation, Tower of Babel, Christianopolis, and other works ${ }^{224}$ - and that thereby overlooked and ignored his goal for reform. Perhaps given the institutional prosecution of Hess and of would-be Rosicrucians by political and academic institutions, ${ }^{225}$ it seems that Andreae deemed it better to dissociate himself from the manifestos and to reject those who attributed their authorship to him and his friends. Andreae withdrew from what had become a dangerous alliance and discussed instead in new ways the reformed society that he and Hess had dreamed about in the first place.

The ideal of a reform of religion, politics, and knowledge remained so close to his heart that he now poured these plans into explicitly fictional writings, and Christianopolis in this regard represented the ideal intellectual community Andreae had hoped for but could not realise. ${ }^{226}$ One of the most remarkable

\footnotetext{
222 Brecht, "Johann Valentin Andreae," 282.

223 Confessio, 45: "[philosophia] theologiae ac medicinae plurimum, jurisprudentiae minimum habeat."

224 See above, section 3.1.

225 On these investigations, see below, section 5.3.

226 This conclusion is also drawn by Dickson, The Tessera of Antilia, 42-43, 56, 81-88, especially ibid., 45: "[...] Andreae never repudiated the ideals of the manifestos; he merely
} 
signs of the continuity between the manifestos and Andreae's later work are those twenty-eight sentences from the Confessio that are included in almost identical form in the Sheath (Theca) of 1616 . While this detail has been used to confirm Andreae's authorship of the second Rosicrucian manifesto, it should also be seen as a testimonial to Andreae's continued belief in the need for a general reformation. It is no coincidence that the first sentence of the 'selfplagiarised' passage reads, as has been mentioned, "while the world is tottering and almost at the end of a period and rushes to its beginnings, God returns the order of nature." 227

Other sentences taken from the Confessio include: "From the revolution of the world we are able to estimate in some way both the future and the present," 228 as well as

He, to whom it has been granted to behold, read, and thereafter to comprehend the great letters of God, which He inscribed on the machine of the world, and which He repeats alternately according to the vicissitudes of the empires, is said to be a magician. ${ }^{229}$

Further repeated sentences concern the microcosm-macrocosm analogy; predictions of future times; the signs in nature, the heavens, and Scripture readable to few and announcing imminent changes; the lion effectuating these changes; the false practice of pseudo-alchemists that was to be rejected; the Book of Nature; the Rosicrucians' magical language to express the essences of things

repudiated - at a time when the so-called "secret brotherhood" of the Rosicrucians has become the butt of many jokes - the use to which these ideals had been put," and ibid., 78: "Why had the Fama been written by Andreae and his friends? Quite simply, to serve anonymously the cause of reform"; as well as by Brecht, "Kritik und Reform der Wissenschaften bei Johann Valentin Andreae," 131-132.

227 Andreae, Theca gladii spiritus, 31, nr. 175: "Iehova mundo labascente, \& propemodum periodo absoluta, ad principium properante; naturae ordinem invertit." Cf. Confessio, 43: "Jehova est, qui mundo labascente, et propemodum periodo absoluta, ad principium properante Naturae ordinem invertit."

228 Andreae, Theca gladii spiritus, 31, nr. 178: "Ex mundi revolutione futura simul \& praesentia aliquo modo metiri quimus." Cf. Confessio, 46: "ex mundi revolutione futura simul et praesentia metiuntur."

229 Andreae, Theca gladii spiritus, 32, nr. 181: "Magus dicitur, cuicunque magnas Dei literas, quas mundi machinae inscripsit, \& per imperiorum vicissitudines alternatim repetit, intueri, legere, atque exinde se erudire consessum est." Cf. Confessio, 52: "Sane cuicunque Magnas illas Dei litteras, quas Mundi machinae inscripsit, \& per Imperiorum vicissitudines alternatim repetit, intueri, legere, atque exinde se erudire concessum; ille quidem (etsi hoc tempore inscius) jam noster est; Atque uti scimus, non neglecturum nostram invitationem: ita vicissim fraudem omnem ejuramus [...]." 
and their own philosophy, redolent of the Adamic language; and the Bible as the greatest work - that is, sentences directly related to the topic of a general reformation as we have untangled it in the previous chapters. Andreae slightly altered some of these sentences, but the general topic remained the same: they provide in a nutshell the overall theme of this study, for which reason the sentences in question are included in the Appendix.

It has been argued that in seeking and finding common ground between the manifestos and Andreae's other writings, scholars have emphasised superficial similarities and have ignored radical differences. ${ }^{230}$ From the perspective of the theme of this work, this criticism looks misplaced. The common ground between the manifestos and Andreae's later works is constituted by Andreae's belief in the need to reform society and its institutions, convinced as he was that, thanks to Christ's sacrifice, it was possible for humans to return to the original splendour of knowing divine and natural secrets-which is fully in agreement with the manifestos' notions. Additionally, the relevance of astrological and alchemical studies and the return to primeval knowledge is clearly voiced in these other writings by Andreae, especially in his Christianopolis.

The role of Hess in the composition of the manifestos was also significant, as many of the apocalyptic themes are his: the destruction of the papal Antichrist by a roaring lion who was to become the ruler of future times, as well as the millenarian imagery according to which another age was on the horizon, all have their origin in Hess' beliefs and expectations. Hess' lion coalesced with Andreae's hopes for a German political ruler and appeared as a spiritually and politically ruling German lion in the manifestos. We may assume that the manifestos' conspicuous optimism and the hope for a new, reformed age was first and foremost due to Hess. The same is true for the traces of Paracelsianism -in all likelihood it was Hess who embedded Paracelsian notions into the manifestos.

It seems that the attempt to trace the various topics related to the overall theme of a reformation back to the presumed authors of the manifestos also sheds light on the contested topic of authorship itself. Brecht and Gilly agree that the contents of the Rosicrucian manifestos were partly inspired by Hess, but they nevertheless deny Hess' direct involvement in the composition of the manifestos for stylistic reasons: both the internal consistency of the manifestos and the use of Latin idioms would point to a single author, Andreae, only. ${ }^{231}$

230 Montgomery, Cross and Crucible, vol. 1, 192.

231 Brecht, "Johann Valentin Andreae," 288; idem, Johann Valentin Andreae, 40, 43, 85; Gilly, Cimelia Rhodostaurotica, 78 ; idem, "Die Rosenkreuzer," 52. 
However, it remains unclear as to why this should be the case, that is, why a collaboration cannot result in a coherent narrative. As for style, besides a handful of letters no works by Hess have survived, which makes it impossible to compare the manifestos to a recognisable style in other writings and to rule out, or argue for, his authorship on that basis. Based on the contents of the manifestos it seems in fact appropriate to consider both Andreae and Hess as the authors of the manifestos. It is precisely from the theme of a general reformation that their combined efforts become visible. After all, it was only thanks to the combination of Hess' Joachimism and Paracelsianism with Andreae's reform plans that the manifestos could arrive at the powerful message that they delivered. 